\title{
Evolution of Water Quality of Lake Balaton
}

\author{
Károly Kutics \\ R\&D Consulting Environmental Services Ltd., Veszprém, Hungary
}

\begin{abstract}
Lake Balaton, a large shallow lake with some $600 \mathrm{~km}^{2}$ surface area, with its $3.5 \mathrm{~m}$ average depth, is among the shallowest lakes in the World and one of the most important lakes in Europe in terms of ecological, economic and cultural aspects. Intervention in the natural environment of lakes, especially shallow ones of high vulnerability and low resilience may result in detrimental and often irreversible changes. In case of Lake Balaton, irreversible changes include the reduction of lake level and subsequent construction directly on the lake shore as well as introduction of foreign species such as eel and silver carp. Reasons for the negative results/impacts of the introduced interventions are: insufficient level of technical or scientific knowledge at the time of planning and implementation; poor decision support systems and mechanisms; insufficient consultation with local people and experts of other fields; lack of integrated approach, both in terms of territorial and interdisciplinary aspects; and pursuing of short term economic or political benefits. Compared to the situation one and a half centuries ago, many of the reasons leading to adverse effects can be eliminated because: technical and scientific knowledge is increasing with high speed and huge amount of monitoring, etc. data are becoming available; decision support systems and mechanisms are getting faster and are improving in complexity; consultation with, participation, and empowerment of local people, stakeholders and a diverse choice of experts are becoming basic requirements in environmental and spatial development policy; integrated approaches both in terms of territorial and interdisciplinary aspects are gathering momentum. It would be of great importance to stop pursuing short term economic gains and political benefits when significant interventions into lake environments are considered.
\end{abstract}

Keywords - Lake Balaton, eutrophication, nutrient load, algal blooms, ecological diversity, water quality, water level fluctuations, watershed, draining of wetlands, reed degradation, drinking water supply, sustainable tourism, carrying capacity

Received: November 1, 2019

Accepted: December 23, 2019

\section{Introduction}

Lake Balaton, a large shallow lake with some $600 \mathrm{~km}^{2}$ surface area, is one of the most important lakes in Europe in terms of ecological, economic and cultural aspects. It is the largest lake by surface area on the continent - not taking Scandinavia and Russia into account. With its $3.5 \mathrm{~m}$ average depth, it is among the shallowest lakes in the World. Characteristics of the Lake are summarized in Table 1. below. Lake Balaton is used for several purposes or, from the viewpoint of the lake, it provides a number of ecological services, i.e. water supply resources, flood control, effluent disposal, food production, recreation, transportation, sustaining food web and ecological diversity, regulating local climate and, last but not least, natural beauty and inspiration. There are 44 municipalities situated around the lake that have direct shoreline. These are considered the primary beneficiaries of the existence of the lake. Lake Balaton Recreational Area (LBRA, mostly called simply "Balaton Region") is a legal entity determined by the

${ }^{1}$ Lóczy L. (1913), Zólyomi B. et al. (1992), Cserny T.et al.(1989) in Virág Á. (1998): Past and Present of Lake Balaton, Egri Nyomda, Eger, pp.904. ISBN 9639060216.
Regional Development Act (Act XXI of 1996 on Regional Development and Spatial Planning) consists of 180 municipalities in the neighbourhood of the lake. It constitutes the largest touristic region in Hungary with some 6 to 8 million registered guest nights. In addition to the 70 thousand households of permanent residents, another 70 thousand holiday houses and apartments are in the Region. (BKÜ Helyzetelemzés 2013) There are 317 municipalities with a total permanent population of 350 thousand people in the watershed of Lake Balaton, which is one of the 4 individual river basin districts (RBD No. 4) in Hungary.

\section{History of the formation of Lake Balaton}

The lakebed of Lake Balaton more or less similar to the present one has been formed at the end of the Pleistocene epoch of the Earth. More specifically, it was formed around the end of the Würm glacial period, about 19 to 17 thousand years ago. ${ }^{1}$ During this period, the watershed of Lake Balaton (and the entire Carpathian Basin) was free from ice cover 


\begin{tabular}{|c|c|}
\hline Item & Value \\
\hline Catchment area (including the lake itself) & $5,774.5 \mathrm{~km}^{2}$ \\
\hline \multicolumn{2}{|l|}{ Of this: } \\
\hline Zala river catchment area (Western sub-catchment) & $2,621.8 \mathrm{~km}^{2}$ \\
\hline Northern sub-catchment & $1,099.5 \mathrm{~km}^{2}$ \\
\hline Southern sub-catchment & $1,464.7 \mathrm{~km}^{2}$ \\
\hline Lake surface at $75 \mathrm{~cm}$ gauge level (survey of year 1975) & $588.5 \mathrm{~km}^{2}$ \\
\hline Volume at $75 \mathrm{~cm}$ gauge level (survey of year 1975) & 1,978 million $\mathrm{m}^{3}$ \\
\hline Average water depth at $75 \mathrm{~cm}$ gauge level (survey of year 1975) & $3.36 \mathrm{~m}$ \\
\hline Maximum water depth at $75 \mathrm{~cm}$ gauge level (survey of year 1975) & $10.36 \mathrm{~m}$ \\
\hline Surface at $100 \mathrm{~cm}$ gauge level (extrapolation from survey of year 1975) & $605 \mathrm{~km}^{2}$ \\
\hline Volume at $100 \mathrm{~cm}$ gauge level (extrapolation from survey of year 1975) & 2.130 million $\mathrm{m}^{3}$ \\
\hline Average water depth at $100 \mathrm{~cm}$ gauge level (extrapolation from survey of year 1975) & $3.52 \mathrm{~m}$ \\
\hline Elevation (above Baltic Sea level) of the Siófok water level zero point & $103.41 \mathrm{~m}$ \\
\hline Elevation (above Baltic Sea level) of the legal shoreline ( $100 \mathrm{~cm}$ level gauge) & $104.41 \mathrm{~cm}$ \\
\hline Area of reed belts inside the legal shoreline (Survey of year 2004) & $12.3 \mathrm{~km}^{2}$ \\
\hline Length of legal shoreline (including harbours) & $274.24 \mathrm{~km}$ \\
\hline Length of legal shoreline at $100 \mathrm{~cm}$ water level (survey of year 1975) & $235.6 \mathrm{~km}$ \\
\hline \multicolumn{2}{|l|}{ Of this: } \\
\hline Natural shoreline (as of year 2006) & $128.1 \mathrm{~km}$ \\
\hline Length of shoreline protection structures & $107.5 \mathrm{~km}$ \\
\hline • Permanent structures / concrete (as for year 2006) & $85.23 \mathrm{~km}$ \\
\hline • Temporary structures (as for year 2006) & $22.95 \mathrm{~km}$ \\
\hline Length of the lake & $76.3 \mathrm{~km}$ \\
\hline Average width of the lake & $7.95 \mathrm{~km}$ \\
\hline Maximum regulation water level (effective from year 2018) & $120 \mathrm{~cm} \pm 5 \%$ \\
\hline Minimum water regulation level (eliminated in year 2018) & none \\
\hline \multicolumn{2}{|l|}{ Characteristics of water balance (averages of the period $1921-2014$ ) } \\
\hline Direct precipitation to the lake & 618 lake mm \\
\hline Inflow & 858 lake $\mathrm{mm}$ \\
\hline Evaporation & 898 lake mm \\
\hline Natural balance of water & 578 lake $\mathrm{mm}$ \\
\hline Outflow & 558 lake $\mathrm{mm}$ \\
\hline
\end{tabular}

Table 1. Physical, morphological and hydrological characteristics of Lake Balaton (Official data established by the CentralTransdanubian Water Management Directorate; KDT VIZIG)

(Fig.1) so the lake is not of glacial origin. Therefore, Lake Balaton is a rather young lacustrine formation, as compared to ancient lakes such as Lake Ohrid, Lake Skadar or Lake Baikal that are estimated to be 4 to 25 million years old. According to a review and synthesis by Virág (1998) of geological and paleolimnological research, at the beginning of the Holocene several smaller, separate lakes existed ${ }^{2}$ (Fig. 2). Due to level fluctuations, wave erosion and deflation these lakes merged about 7 to 5 thousand years ago resulting in the present shape of the lake. In the merging process of the proto- lakes changes in the flow direction of Zala river might have played an important role. Gábris \&Mari $(2007)^{3}$ determined that Zala river flew northward until the mid-Pleistocene but changed course and was connected with the so called Ancient or Lower Zala river, that flew southward into the Dráva river. Later, at the end of Pleistocene, Lower Zala river turned westward due to the subsistence of the Lower Zala region. Since Zala river carries about half of the discharge into the present - day Lake Balaton, appearance of Zala river as the
2 Lóczy L. (1913): A Balaton Tudományos Tanulmányozásának Eredményei, A Magyar Földrajzi Társaság Balaton Bizottsága, Budapest, pp.644. (in Hungarian).
${ }^{3}$ Gábris Gy. \& Mari L. (2007): The Pleistocene beheading of the Zala River (West Hungary), Földrajzi Értesítő 2007. LVI. évf. 1-2. füzet, pp. 39-50. 


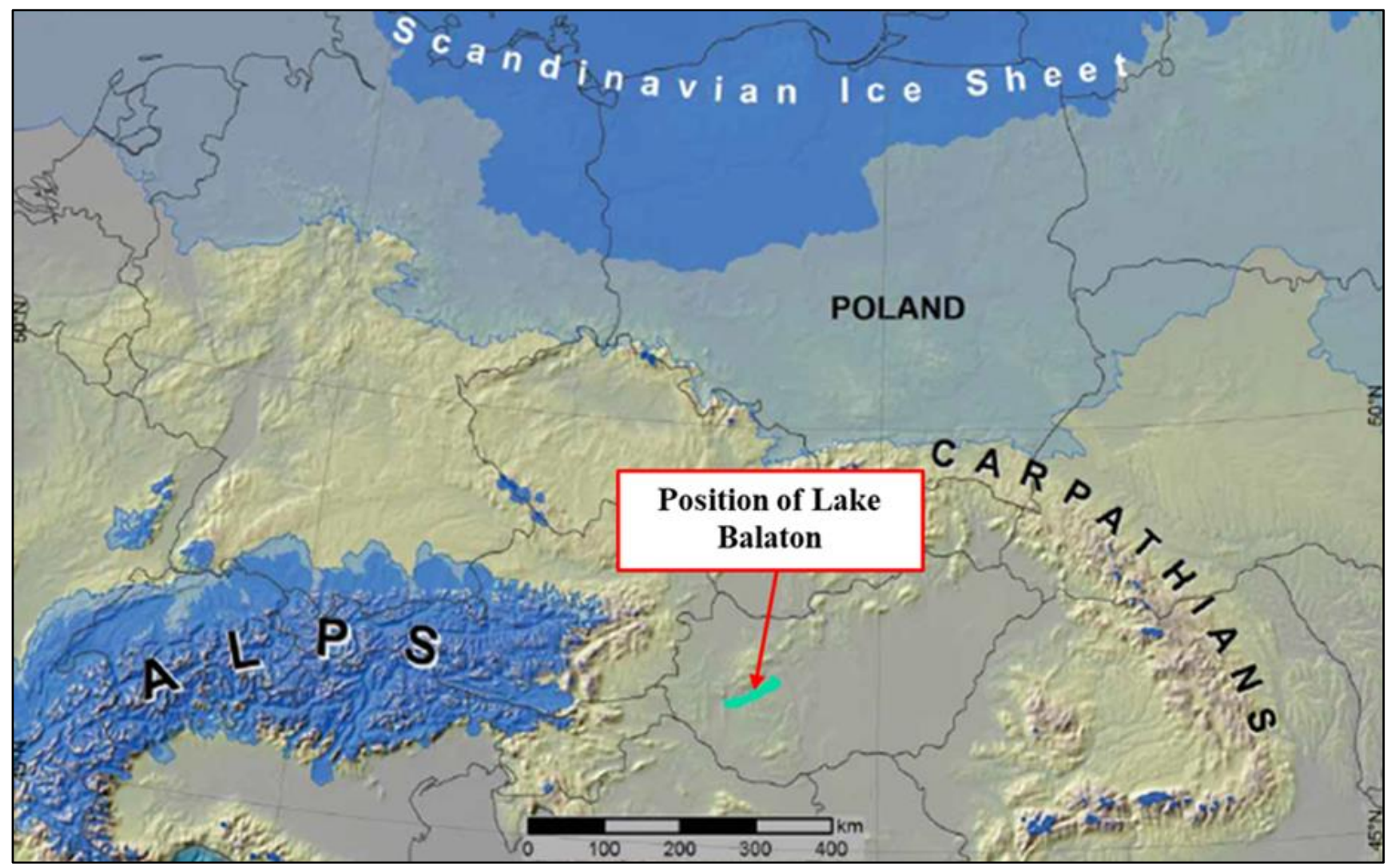

Figure 1. Ice cover at the last glacial maximum, approx. 20,000 years ago (blue), and at its maximum during the Quaternary epoch (light blue) . based on Zasadni \& Klapyta(2014) .

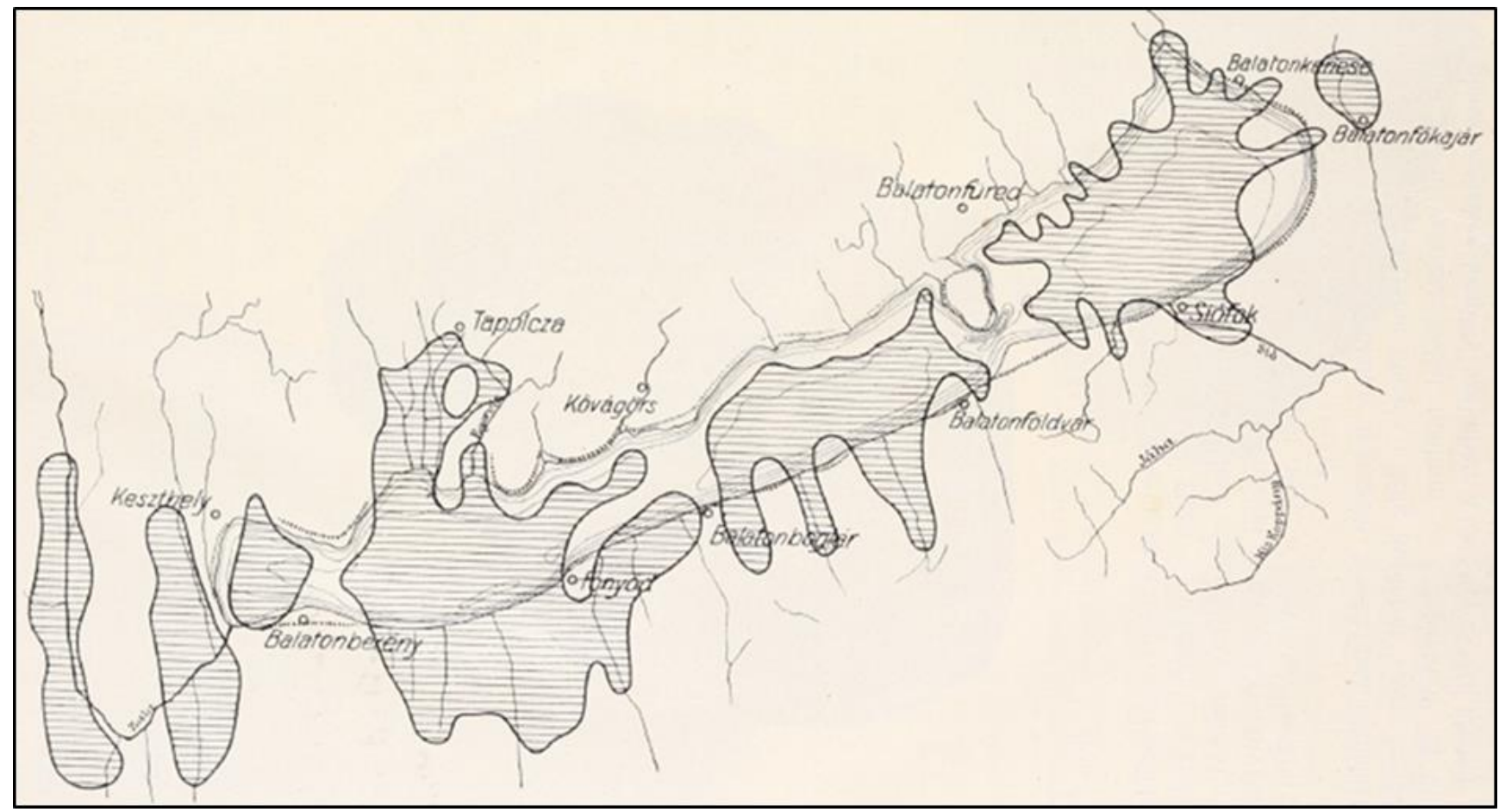

Figure 2. Separate lakes (hatched areas) at the end of Pleistocene and the present lakebed of Lake Balaton (Lóczy, 1913) 
main tributary of the basin could play a key role in the interconnection of the former proto-lakes that eventually formed Lake Balaton. A study by Sümegi $(2011)^{4}$ provides information on the water quality of the proto-lakes or Lake Balaton itself. From boring cores of up to $5 \mathrm{~m}$ deep (corresponding some 14 thousand years BP), he reconstructed the trophic state of the lake(s) through the analysis of mollusc species, etc. He identified littoral, paludal and lacustrine species from different layers suggesting wide fluctuations in lake levels. Also, species characteristics of oligotrophic, mesotrophic and eutrophic conditions were also found thousands of years before the beginning of human productive activities. Based on Sümegi (2011), some characteristics of a sediment core from Fenékpuszta (called Valcum in the Roman Ages) are shown in Table 2 below.

Table 2. Changes in the trophic status of Lake Balaton and its proto-lakes (based on Sümegi (2011))

\begin{tabular}{|c|c|c|c|}
\hline $\begin{array}{c}\text { Sediment core } \\
\text { depth, cm }\end{array}$ & Year BP & $\begin{array}{c}\text { Trophic } \\
\text { status }\end{array}$ & $\begin{array}{c}\text { Water } \\
\text { depth } \mathrm{m}\end{array}$ \\
\hline $278-247$ & $11,600-8,600$ & Oligotrophic & Lake, 3+ \\
\hline $247-243$ & $8,500-8,000$ & $\begin{array}{c}\text { Volcanic } \\
\text { ash? }\end{array}$ & \\
\hline $243-106$ & $8,000-4,000$ & Mesotrophic & Lake \\
\hline $106-$ & $4,000-600$ & $\begin{array}{c}\text { Eutrophic }- \\
\text { oligotrophic } \\
3 \text { cycles }\end{array}$ & $\begin{array}{c}\text { Changing } \\
\text { lake/marsh }\end{array}$ \\
\hline
\end{tabular}

Level fluctuations are well documented from other studies, such as Cholnoky (1936), Bendeffy $(1968)^{5}$. On Fig. 3 the data of Bendeffy referring to the A.D. period completed with recent water level measurement data are shown. Water level (and so lake volume and surface) of the lake changed within wide limits. Systematic regulation of the lake level started in 1863 with the commencement of the outlet sluice on the Sio canal in the town of Siófok. Direct reason of the introduction of level control was the construction and operation of a railway line along the southern shore of the lake, since high water level with wave action resulted in damage to the railway tracks. Water level dropped considerably, resulting in a host of problems that emerged since then.

As it was pointed out above, lake level changes in the Holocene changed the trophic status of the lake, resulting in natural eutrophication when the water level dropped and paludal conditions emerged. The artificial reduction and control of lake level coupled with anthropogenic eutrophication a century later led to serious water quality problems.

\section{Human interference with the Lake and its environment}

The area around Lake Balaton was very sparsely populated in the Middle Ages and even at the beginning of the 20th century (Virág Á. (1998)). Although the lake provided some ecosystem services such as drinking water, food (fish, crayfish) and construction material (reed, bulrush), up to the

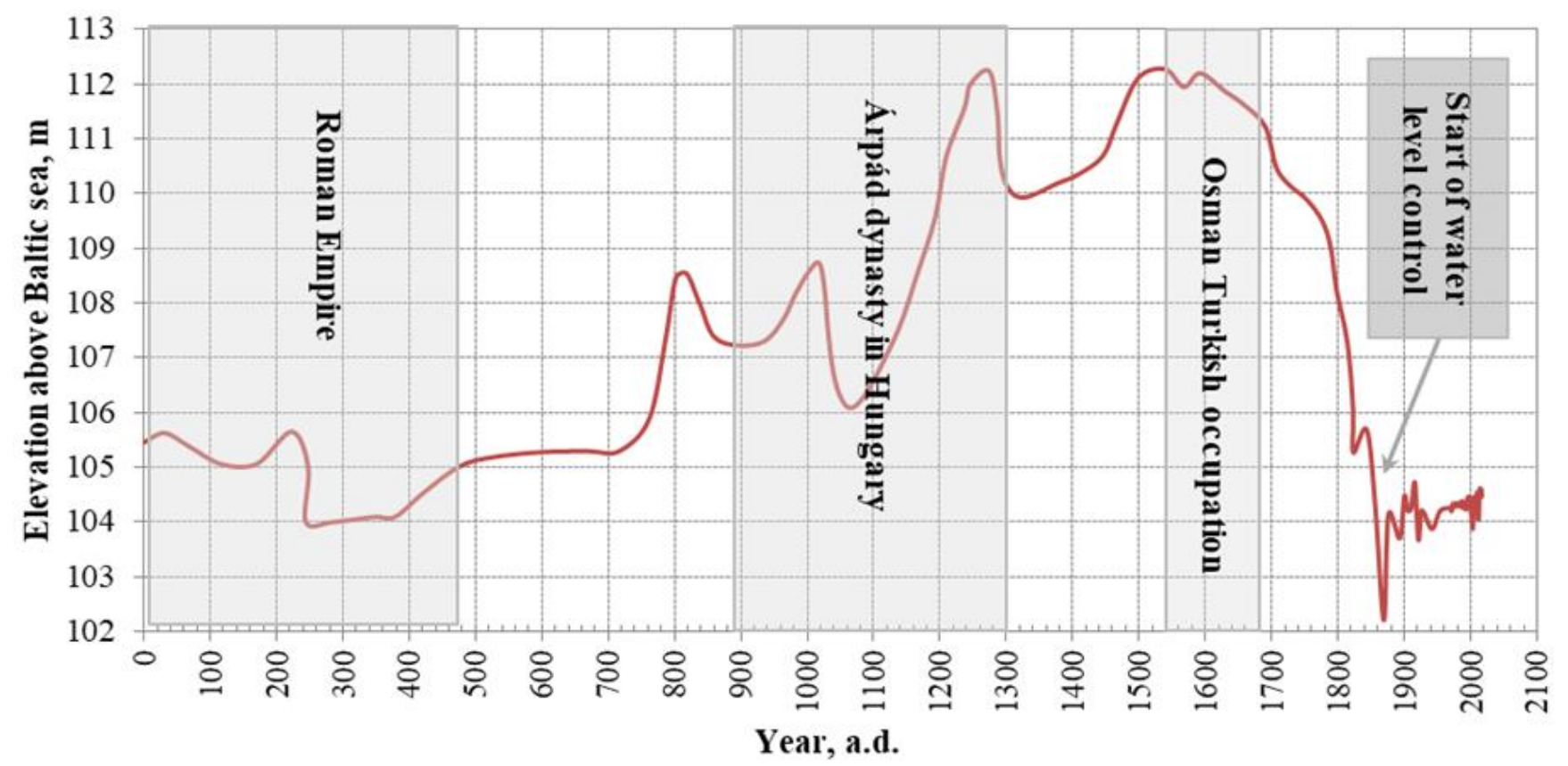

Figure 3. Reconstruction of historic water level changes of Lake Balaton. (Developed on the basis of Bendeffy, 1968. and www.hydroinfo.hu)

${ }^{4}$ Sümegi, P. (2011): The Results of the Archaeomalacological Investigaton of the Core Sequences from Balaton and Little Balaton Basins, Archeometriai Mühely 2011/2, HU ISSN 1786-271X., p.137-156
${ }^{5}$ Cholnoky J. (1936): Balaton, Franklin, Budapest, pp.137. Bendeffy L. (1968): Changes of the water level of Lake Balaton from the Neolithic age to Recent. (A Balaton vízszintjének változásai a neolitikumtól napjainkig, In Hungarian). Hidrológiai Közlöny, 48, 257-263. 
beginning of the $19^{\text {th }}$ century, up to the beginning of the 19 th century, the lake and its surrounding marshlands were rather a burden than a blessing for the people inhabiting the area since occasional flooding of the lake damaged crops and made transportation around the lake difficult, if not impossible. Perhaps the only benefit of the lake in the 16th and $17^{\text {th }}$ centuries was that its extremely high water level (Fig. 3 ) and the flooded marshlands hindered the advance of Osman Turkish occupation and provided refuge for the local population. After the Turkish were driven out of the country at the end of the 17th century, the tributaries and the outflow (Sió river) were utilised as hydropower for water mills. However, the mill dams along the Sió river maintained high water levels both in Lake Balaton and the adjacent marshlands making agricultural utilization of land and transportation of agricultural goods very difficult. The situation was recognized as a problem in the middle of the 18th century, and the start of a series of (the numerous) human interventions in the Lake Balaton environment can be dated to this period (Virág Á. (1998)).

The first actions were intended to reduce the water level and dry up some of the marshlands to improve the conditions of road transport and provide additional arable land. The first recognition of coordinate action came in 1751 when Queen Maria Theresa issued a decree to remove 18 mill dams along the Sió river (the only outflow from the lake). Though this decree was never executed, a watermill in Siófok village was indeed removed in 1822 resulting in a $1 \mathrm{~m}$ level drop of the lake (Virág Á. (1998)). During the next 4 decades, several actions were intended to reduce the water level of the lake, to facilitate road building, draining of swamps, regulating river mouth sections and eventually the building of a railway line along the southern shore. These actions reduced the volume and surface area of the lake but did not have any recorded consequence on water quality. (One reason might have been the fact that "water quality monitoring" did not exist at all at the time.) Draining of extensive marshlands and forcing rivers between embankments (mostly Zala river, the largest tributary to the lake) certainly had one serious consequence: accelerated silting of the lakebed, especially at the southwestern end of the lake. However, since the pollutant and nutrient load of the tributaries must have been at a very low level, water quality deterioration did not occur. Dropping the water level during this period by some 3 meters resulted in the practical disappearance of the hypolimnion, increased sediment resuspension and sensitivity to changes in the hydro-meteorological conditions.

Lake level regulatory actions continued since occasional flooding occurred even after the construction of higher and higher capacity sluices at the outflow in $1892\left(50 \mathrm{~m}^{3} / \mathrm{s}\right), 1921$ and $1947\left(80 \mathrm{~m}^{3} / \mathrm{s}\right)$. The better regulation of water level allowed the construction of more and more infrastructure right on the lake shore - in most cases on former marshland areas or even in the former lake bed (Fig. 4). Losing the protective marshlands with extensive vegetation, building up the shoreline with artificial (mostly concrete) structures increased the vulnerability of the water quality of the lake to both natural and human impacts. More building and better roads meant more population and the start off of tourism. As early as in 1938, the number of recorded guest nights reached 2 million per year (Kutics K. (2015)). At the same time, number of summer houses (built by better-off people living in Budapest and other cities) increased with an amazing pace.

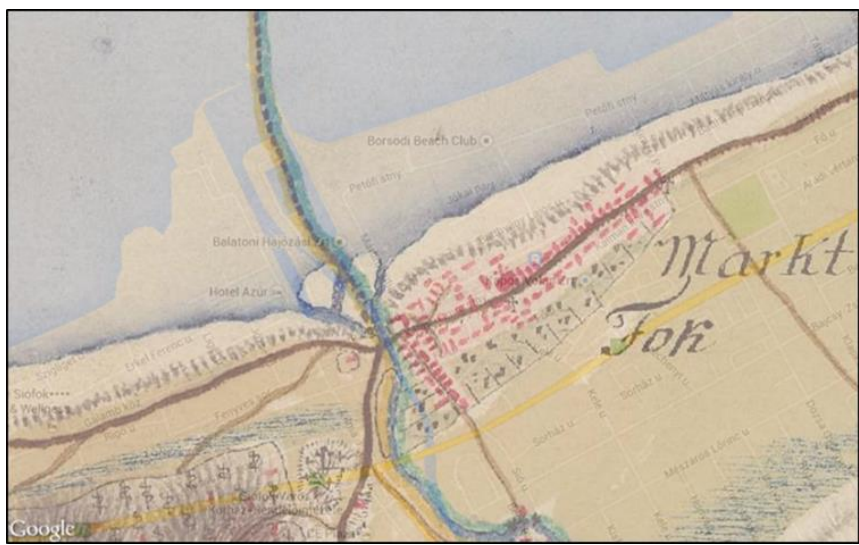

Figure 4. Siófok and its neighbourhood in the 18th century and at present on overlaying maps (source: https://mapire.eu/hu/map/firstsurvey-hungary/)

An example of wind induced sediment resuspension is shown in Figure 5, where 4 wind events are shown for the Siófok Basin (deepest and widest one). Wind speeds of up to some 6 $\mathrm{m} / \mathrm{s}$ did not result in any significant resuspension of bottom sediment. Resuspension was triggered by winds of 8 to $9 \mathrm{~m} / \mathrm{s}$, and a medium storm of up to $16 \mathrm{~m} / \mathrm{s}$ wind speed resulted in extremely high turbidity values in the water column. The most important implication of this behaviour is the high mass transfer rates between the sediment surface and the water column. As a result, phosphorus exchange with the sediment intensifies, and the sediment my serve as a source of phosphorus at almost any time of the year, as opposed to deeper monomictic or dimictic lakes. Simulations conducted for the Siófok Basin at fetch distance $6.24 \mathrm{~km}$ (NW wind, midpoint of basin) by the shallow lakes wave equations (CERC, 1977, US-ACE, 1984) showed that at a reference wind speed of $8 \mathrm{~m} / \mathrm{s}$ the resuspension depth equals to $84 \%$ of the mean depth $(3.81 \mathrm{~m})$ of the basin at $75 \mathrm{~cm}$ gauge level (i.e. recent conditions), but it would be reduced to only $45 \%$ of it when the mean depth was doubled (roughly the conditions before interventions to reduce lake level started in the 19th century). This indicates that sediment-water mass transfer was less intensive before lake level reduction and lake-wide sediment resuspension was a rather rare event limited to extremely high wind conditions (i.e. storms) exceeding $25 \mathrm{~m} / \mathrm{s}$. 


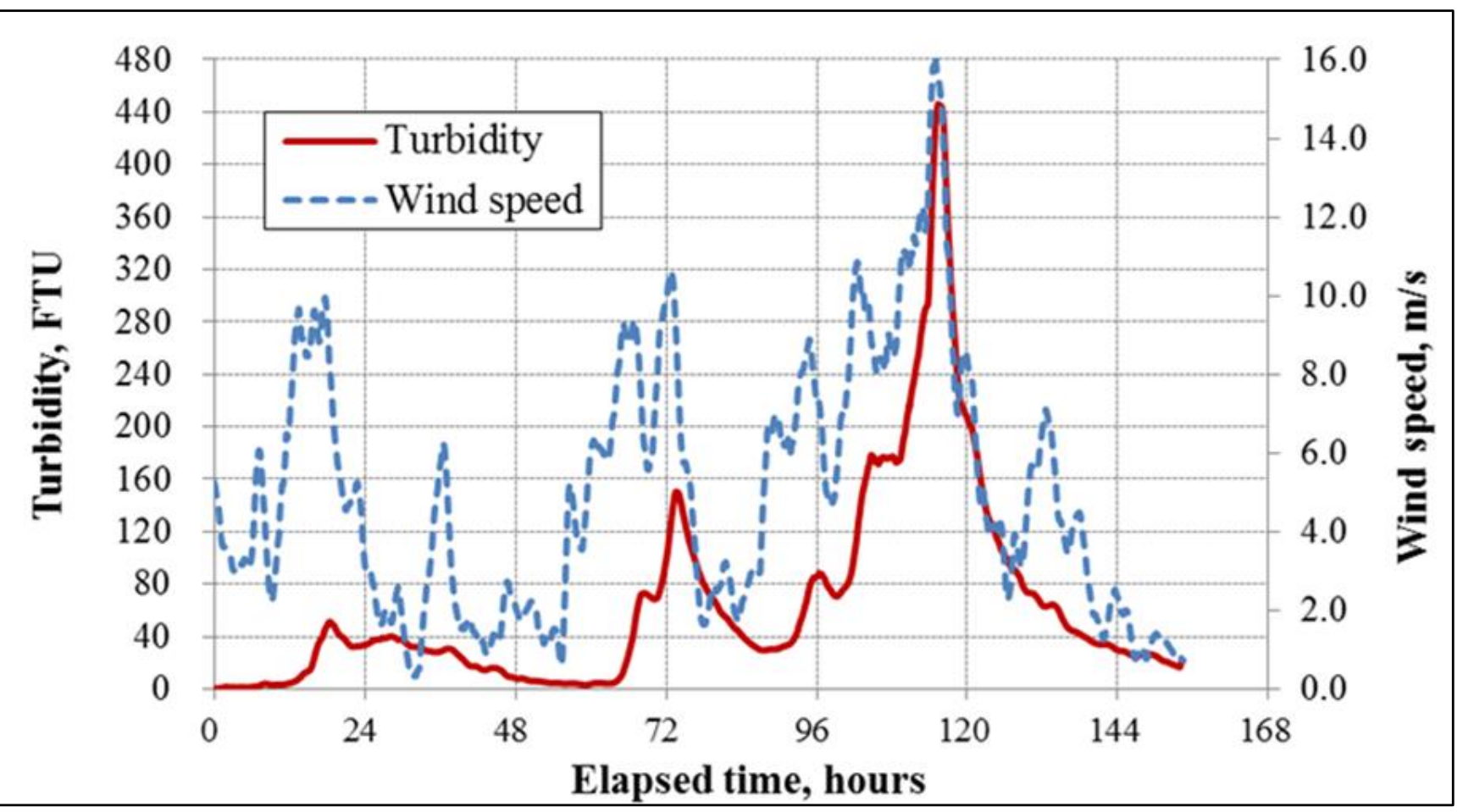

Figure 5. Wind induced changes in turbidity in the water column due to bottom sediment resuspension (Basin 4 centre, Siófok, from June 1, 2012, 0:00 hour; 10-minute frequency of measurement, 7-order smoothing, baseline-corrected. Raw data were provided by the BIR monitoring system of LBDCA).

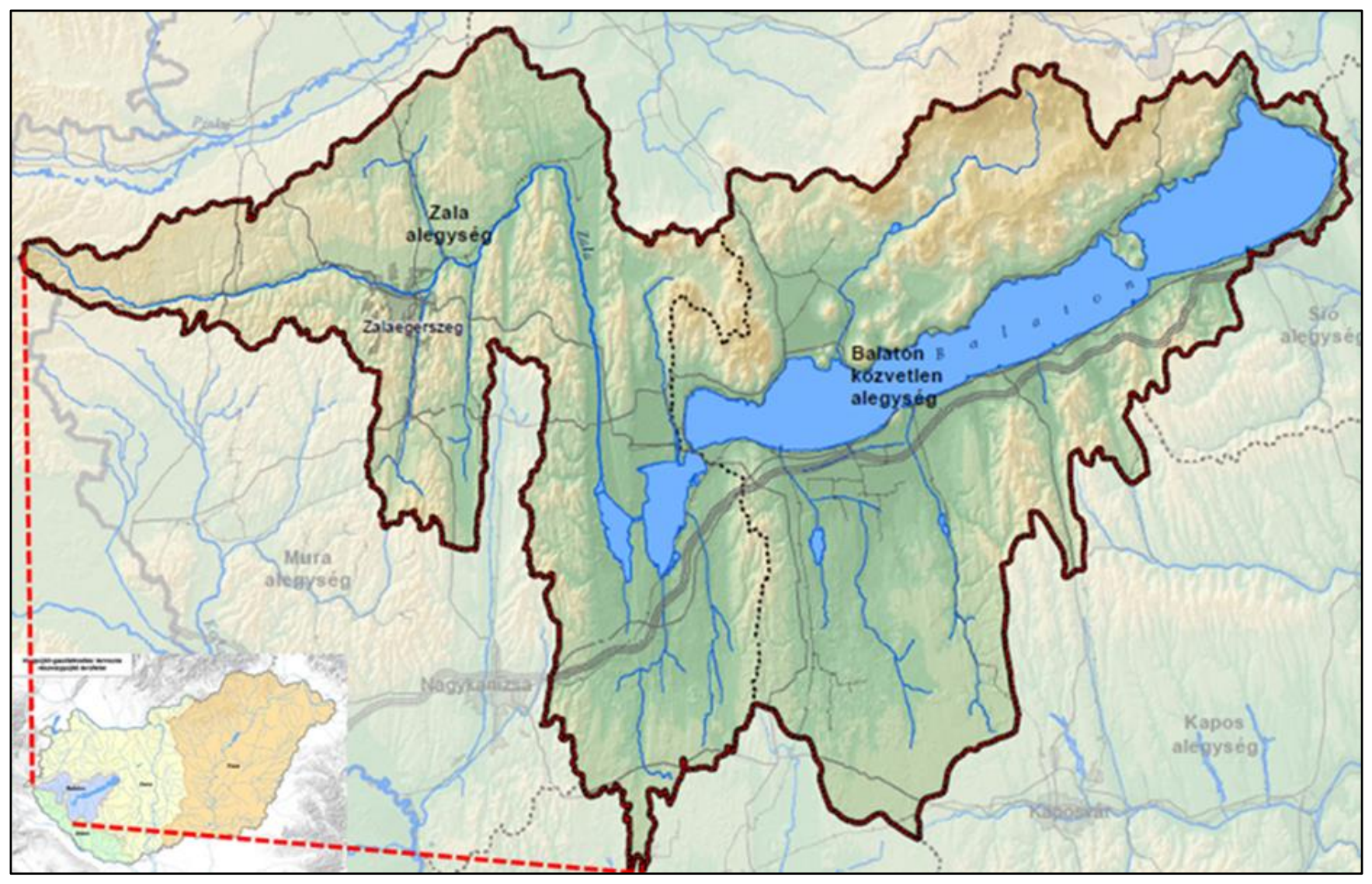

Figure 6. Lake Balaton watershed is one of the 4 separate "river basins" in Hungary defined in accordance with the EU-Water Framework Directive (Based on: KDT VIZIG: Lake Balaton River Basin Management Plan, 2016 www.vizeink.hu) 
The present - day Lake Balaton and its watershed with its tributaries are shown in Figure 6. Zala river on the west side is by far the largest tributary constituting roughly half of the discharges into Lake Balaton.

Following the introductory part on human interference, a systematic review is attempted to list and describe the impact of measures that resulted in negative and positive impacts on the environment and water quality of Lake Balaton. Measures with mostly negative impacts are as follows:

Railway construction and subsequent water level reduction to protect the tracks:

1) Draining of wetlands and marshes around the lake

2) Permitting and/or tolerating construction right on the lake shore and subdivision and privatization of land facing the lake shore

3) Building concrete and stone shore protection structures

4) Promotion of mass tourism without proper environmental and transport infrastructure

5) Excessive use of fertilizers on the agricultural land of the watershed

6) Creation of large-scale livestock breeding farms on the watershed

7) Development of drinking water supply without proper sewer development

8) Introduction of foreign/invasive species, e.g. eel, silver carp, etc.

9) Agricultural land fragmentation through reprivatization in the 1990s.

Consequences of railway construction were already mentioned. The other measures are going to be described below.

\subsection{Draining of wetlands and marshes}

Figure 7. shows areas that used to be either lake water surface or shallow wetlands throughout the middle ages. These wetlands partially and occasionally dried up after the introduction of level control in 1963. (However, due to the low discharge capacity of the Siófok Sluice and the Sió Canal level control was of poor quality and year-to-year changes as much as $1 \mathrm{~m}$ could occur.) Nevertheless, landowners in the vicinity of wetlands saw an opportunity to convert marshes into arable land and draining associations were formed as early as in the first half of the 18th century. Draining activities picked up pace after 1863, and large pieces of marshes along the southern shore as well as along the downstream section of Zala river (by far the largest tributary) were converted to arable land by the 1920 s.

The draining interventions resulted in the loss of about 300 $\mathrm{km}^{2}$ of marshlands, and a water storage capacity of 250 to 300 million $\mathrm{m}^{3}$ (i.e. some $15 \%$ of the present volume of Lake Balaton). Other adverse impacts are the increased siltation of the lake especially near the Zala river mouth, loss of biodiversity (though no baseline data exist for comparison), and more frequent reed and peat fires in years of drought.
Agricultural land gained by draining of marshlands (Fig. 8.) was not well suited for cereal or other, important crop production. Perhaps the only positive impact was that draining made possible to construct permanent transportation routes and roads through the former swamp areas.

\subsection{Construction right on the lake shore and subdivision of land}

Following water level control (and level reduction) as well as marshland draining operations, construction near - or right on - the shoreline became possible and hotels, mansions and summer houses were built. Before World War I, the extent of these constructions was small since Lake Balaton was not a primary holiday destination being the North coast of the Adriatic Sea part of the Austro-Hungarian Empire. After losing the sea cost, Lake Balaton became the "Hungarian Sea", the primary domestic summer holiday destination, and more buildings and access roads were constructed. The land right on the shore or a few tenths of meters from it became private properties with their own access to the lake. Most of the constructions occurred after WW II - during a long period of reckless land management - requiring the construction of shore protection structures as well.

In this process, small plots of land were acquired by citizens and/or legal persons (economic and political entities, trade unions, etc.). The main motivation of citizens was investment in a summer house (the only such activity tolerated by the communist system from 1947 to 1989), entering (the mostly tax evading) private accommodation market due to the increasing interest of domestic, German, Polish and Czechoslovakian tourist.

The impacts of these interventions (or rather noninterventions, i.e. the lack of appropriate land use and environmental planning) were the reduced access of local residents and tourists to the lake shore; direct pollution of lake water with nutrients and chemicals through agriculture, leaking cesspools and landfills, direct wastewater discharge ((Némethy and Molnár, 2014), car washing, lawn irrigation, boat paint residues, as well as industrial pollution from the Nitrokémia Industries in Balatonfüzfó and the Hungarian Shipyard and Crane Factory in Balatonfüred; pressure to build additional concrete walls at the shoreline; degradation of reed stands, and illegal landfill (often using construction wastes) of lake water surfaces.

Reed degradation occurred due to the construction of ca. 2000 „private” passages and boat piers along the southern shore amounting to some 10 hectares direct loss of reed stands and much more due to wave action, etc. damage (Fig. 9) (Pomogyi P. (2015))

A comparison of Lake Balaton to other shallow lakes in Table 3 indicates very well the excessive amount of buildings and infrastructure around the shore of Lake Balaton. Lakes No.1 to No.6 are in Florida, while No. 7 and 8 are in Austria/Hungary and Hungary. The average of built-up shoreline percentage is 21.7 \% for Lakes No. 1 to No. 8, while it is $68 \%$ for Lake Balaton. The Southern shoreline of Lake Balaton is especially far from natural conditions with builtup percentage of $91.6 \%$ (Kutics, K. (2013)). 


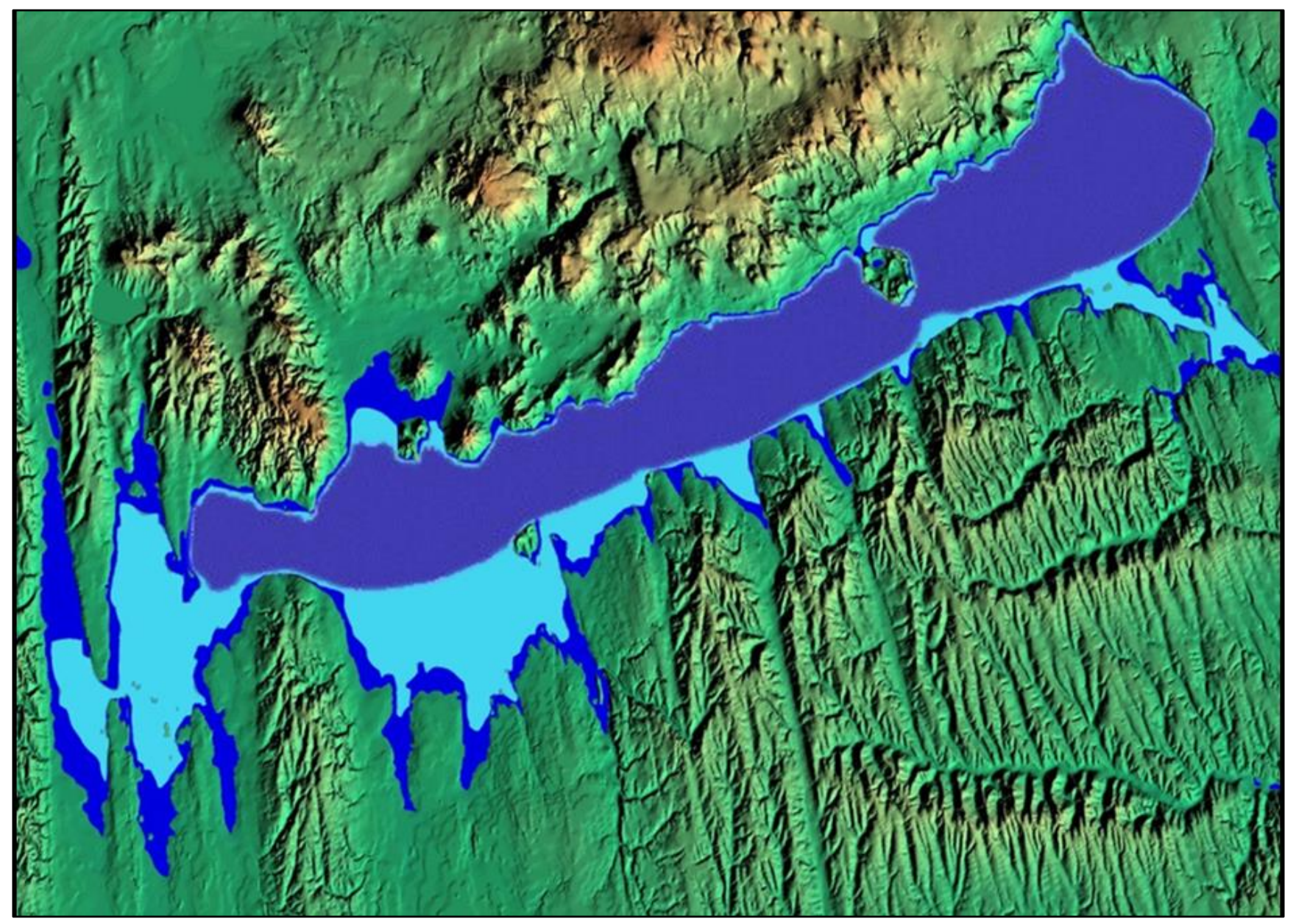

Figure 7. Lake Balaton surface at different water level elevations. (104 m above Baltic Sea level represents recent situation, $105 \mathrm{~m}$ is immediately before the opening of the Siófok sluice, while $110 \mathrm{~m}$ level is typical of the 18 th century.

Source: http://www.vkkt.bme.hu/feltoltesek/2010/10/kisbalaton szf.ppt

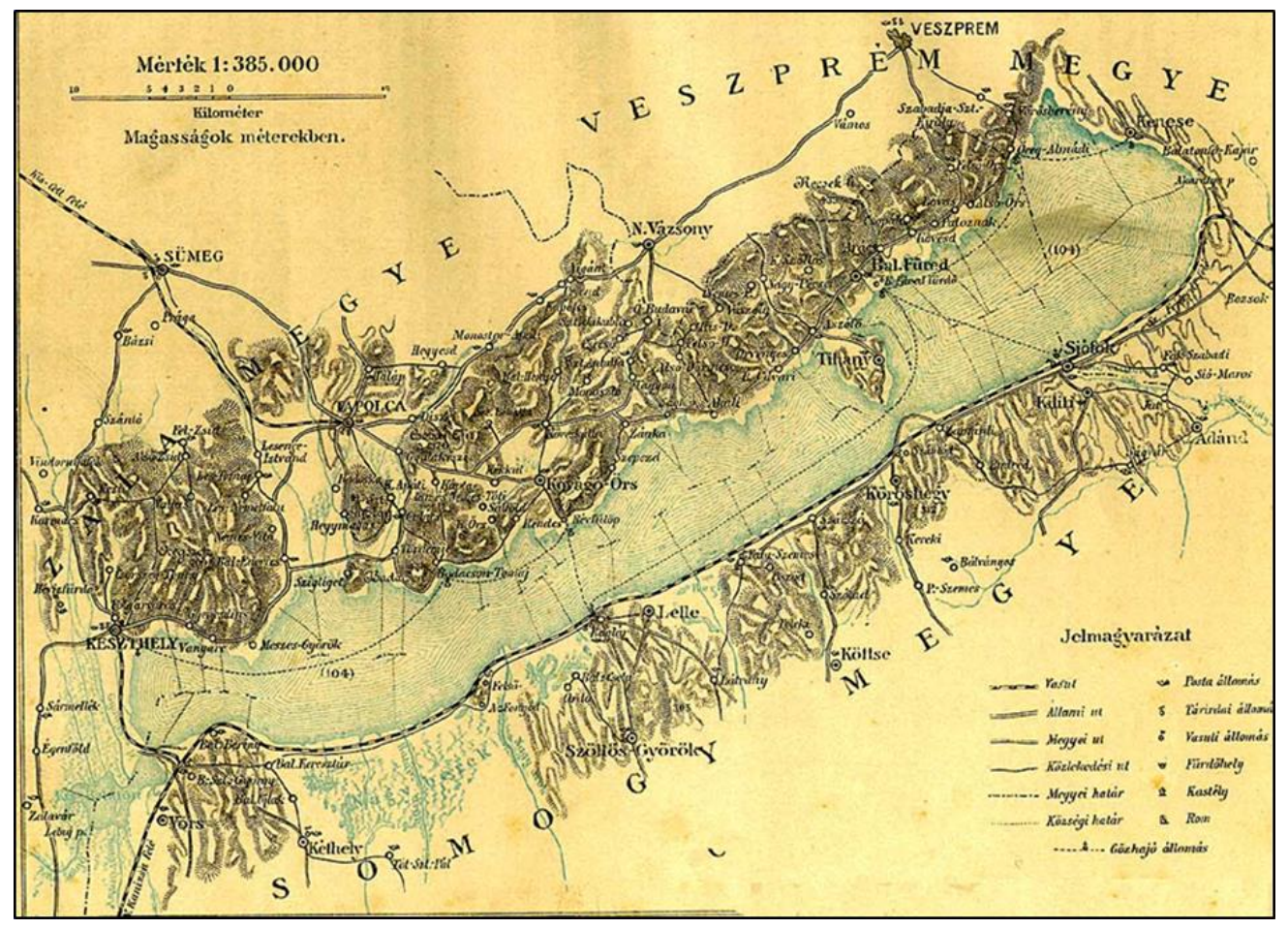

Figure 8. Lake Balaton and its surrounding marshlands at the end of the $19^{\text {th }}$ century. Until the 1860 s, the main objectives of regulation of Lake Balaton and its water system were the connection of Lake Balaton with the Danube, establishing inland navigation, the safety of the Balatonfüred port, the safety of the southern railway and gaining agricultural land around Lake Balaton, mostly by draining the marshes of the southern shore, Zala river and Kis (Little) Balaton area. Marshlands drained after the water level control was introduced are indicated with light blue hatched areas. Map source: A Pallas Nagy Lexikona ("The Great Lexicon of Pallas", Budapest, 1893-1897). 


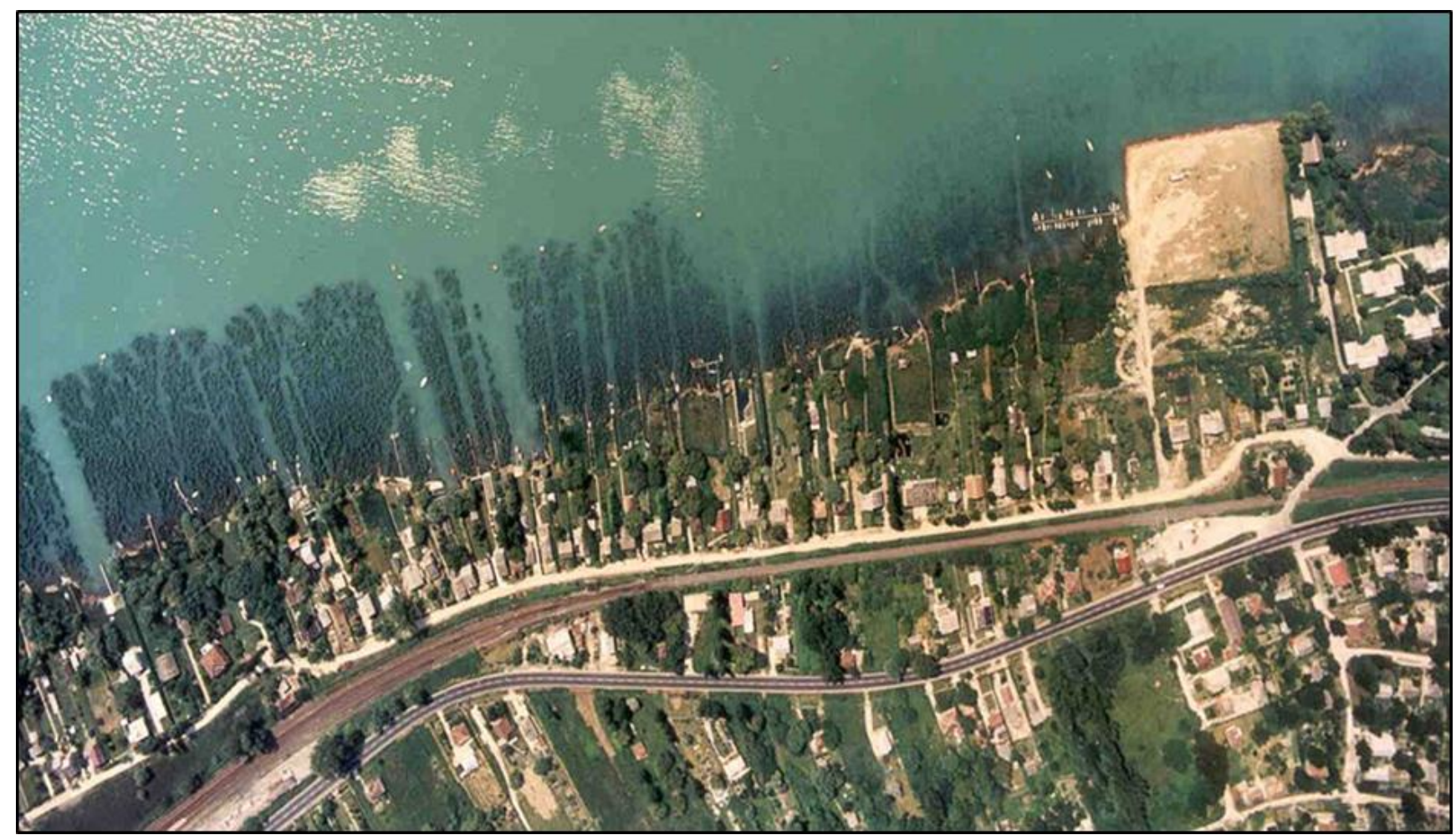

Figure 9. Summer houses on the lake shore. Private entrances to the lake destroyed reed stands and resulted in direct water pollution and loss of habitat. (Source: Google Earth, 2005, shoreline of Balatonkenese township)

\begin{tabular}{|r|l|r|r|r|r|r|}
\hline No. & \multicolumn{1}{|c|}{ Lake name } & Area km² & Mean depth m & \multicolumn{1}{|c|}{$\begin{array}{c}\text { Shoreline } \\
\text { length* } \mathbf{m}\end{array}$} & \multicolumn{1}{c|}{$\begin{array}{c}\text { Built-up shoreline } \\
\text { length* } \mathbf{~ m}\end{array}$} & $\begin{array}{c}\text { \% of built up } \\
\text { shoreline }\end{array}$ \\
\hline 1 & Apopka & 125.0 & 4.0 & 51,300 & 5,700 & 11.1 \\
\hline 2 & Kissimmee & 141.4 & 2.0 & 74,564 & 3,900 & 5.2 \\
\hline 3 & George & 186.2 & 2.4 & 67,021 & 8,000 & 11.9 \\
\hline 4 & Istokpoga & 108.0 & 1.2 & 49,000 & 11,500 & 23.5 \\
\hline 5 & Okeechobee & 1894.0 & 2.7 & 169,524 & 43,300 & 25.5 \\
\hline 6 & Tohopekaliga & 91.9 & 1.5 & 57,133 & 20,600 & 36.1 \\
\hline 7 & Neusiedler / Fertő & 320.0 & 1.2 & 95,560 & 18,600 & 19.5 \\
\hline 8 & Velence & 25.0 & 1.6 & 11,260 & 4,560 & 40.5 \\
\hline 9 & Balaton total & 594.0 & 3.3 & 199,959 & 135,952 & 68.0 \\
\hline & Balaton South shore & - & - & 82,525 & 75,600 & 91.6 \\
\hline & Balaton rest of shore & - & - & 117,434 & 60,352 & 51.4 \\
\hline
\end{tabular}

Table 3. Percentage of built-up shorelines at selected large shallow lakes of massive recreational use. Lengths were measured on Google Earth images at about 1:5,000 map scale. Built-up area was defined as any artificial environment including buildings, harbours, parking area, roads, railway and beaches for bathing that are situated directly on the shoreline or in its 100 m vicinity. (Kutics, 2013). 


\subsection{Concrete and stone shore protection structures}

Concrete walls and stone rip-rap were constructed along about $45 \%$ of the shoreline of Lake Balaton. Such constructions started at the end of the 19th century and accelerated after 1945. The purpose of shoreline protection structures was to prevent the potential damage to buildings, railways, roads and other artificial structures/property by wave erosion and ice dilatation/drifting (Figure 10). The impacts of the intervention include the loss and interruption of habitat in the littoral zone, loss of about 4.3 to $6.9 \mathrm{~km}^{2}$ of reed stands and loss of spawning areas for certain indigenous fish species. It was found (Kutics, 2008) that there is a close correlation $(\mathrm{R} 2=0.78)$ between the length of concrete shore protection structures and the annual fish catch in Lake Balaton. In addition, self-purification potential of the lake was reduced since the floating debris cannot be removed by wave action due to the almost vertical concrete walls. Sandy beaches apparently disappeared and there are great efforts (and huge costs incurred) now to restore some negligibly small sections into "original" conditions. It is apparent that all these changes had a strong and harmful influence on water quality and biodiversity (Herodek S. et al, 1988) continued up to the mid-1980s. The primary purpose was to produce foreign (convertible) currency revenues and to raise the standards of living of citizens through providing recreation opportunities inside the "iron curtain" (Figure 11). These interventions resulted in the overload of water supply facilities with regular water shortages, increase of the pollutant load of Lake Balaton, further reduction of the free access of "ordinary people" (e.g. local permanent residents) to the lake shore, hasty development of water supply without sewer development and sewage treatment. Later, long term plans to develop sewage treatment facilities resulted in considerable excess sewage treatment capacity (and unreasonably high treatment costs) after mass tourism peaked out.

\subsection{Excessive use of fertilizers on the watershed}

In the 1950s and especially at the beginning of the $1960 \mathrm{~s}$, the so-called "collectivization" (i.e. confiscation and nationalization) of agricultural land resulted in reduced productivity. To improve the situation large, state-controlled farms were enforced to use cheap fertilizers and pesticides subsidized by the state, often in great excesses. This intervention resulted in the accelerated eutrophication of

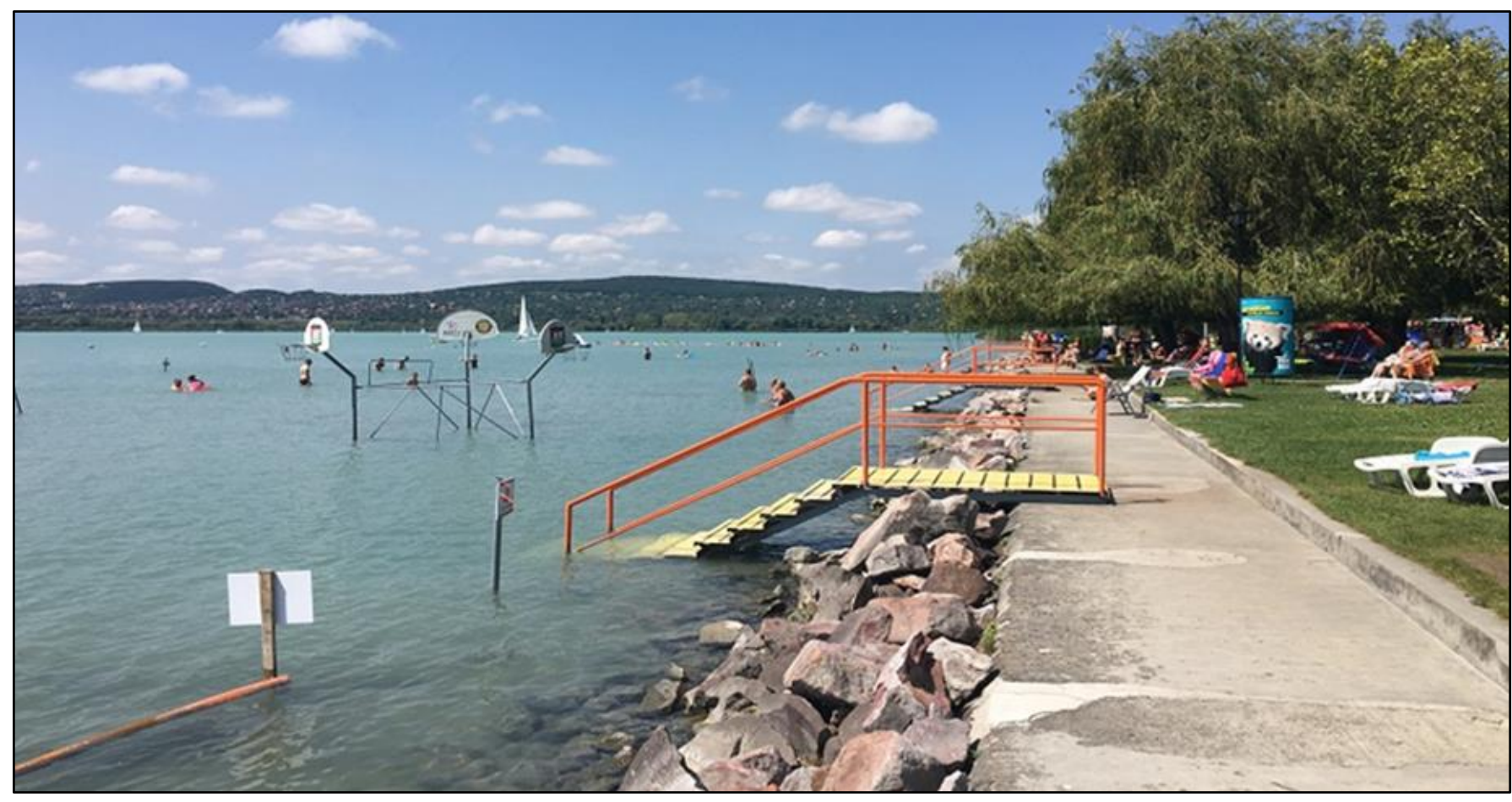

Figure 10. Concrete and stone rip-rap shore protection at Lake Balaton. (Source: www.google.hu)

\subsection{Promotion of mass tourism without proper infrastructure}

The first regional development plan of the Lake Balaton region (the very first such territorial plan in Hungary) was approved by the government in 1963 (Virág Á., 1998). For the first time, it declared that the primary function of the Lake Balaton region (the Lake Balaton Recreational Area, LBRA) is tourism and recreation. Construction of state owned, relatively cheap hotels and camp sites, trade union and Communist Party resort houses was started in the 1960s and surface waters including Lake Balaton, nitrate pollution of groundwater, acidification of soil and occasional pesticide pollution. After the political changes in 1990, fertilizer use dropped substantially. See more detailed analysis in Section 4.7.

3.6. Formation of large-scale livestock breeding on the watershed

Another phenomenon accompanying the creation of large state-controlled farms was the introduction of concentrated 
livestock breeding facilities that used liquid manure technology. However, appropriate manure treatment hardly existed. The only treatment was land application of some of fish species. Having no natural predators and difficult to catch, aging population of silver carp is considered a "biological bomb", i.e. it is feared that large old species may

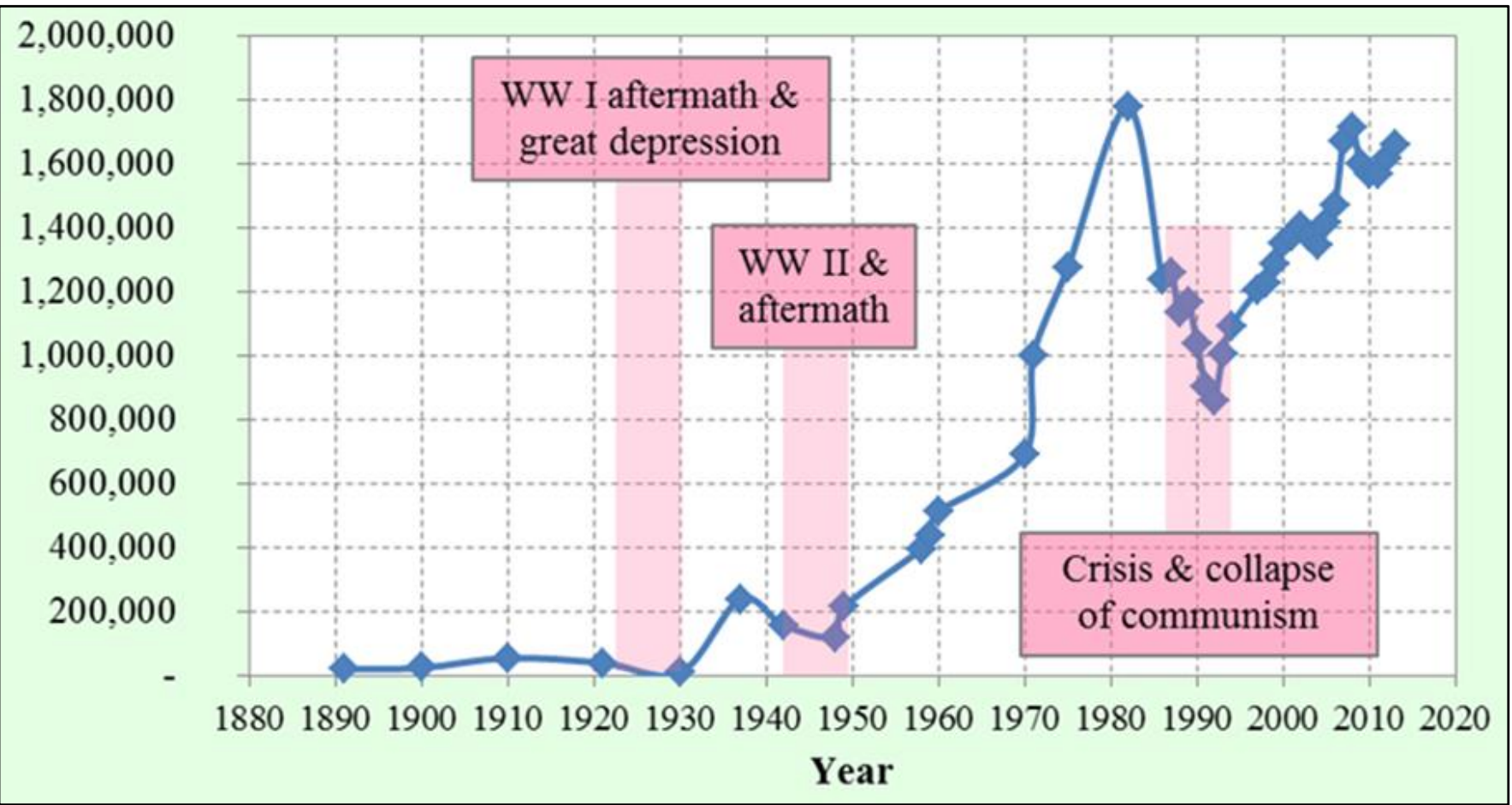

Figure 11. Exponential increase, peak out, decline and recovery of the number of lodging guest in commercial accommodations in the Lake Balaton region (Constructed based on: KSH, MT Zrt., Rátz T., 1999, Virág Á., 1998)

the liquid manure without consideration of the vulnerability of surface and groundwater resources. This resulted in similar impacts as in case of fertilizer use, i.e. pollution and eutrophication of surface and groundwater resources (Somlyódy L., van Straten, G., 1986)

\subsection{Development of drinking water supply without sewer development}

Drinking water supply systems were developed throughout the region from the late 1950s. The purpose was to provide safe drinking water - first mainly to recreational facilities and holiday houses, later for the whole population in the region. This measure led to a large increase in water consumption and inadequate sewage disposal since most of the houses depended on (leaking) cesspools. From 1960 to 2010, an estimated 2400 tons of phosphorus of sewage origin was released into the environment in lakeshore communities before sewage treatment caught up with drinking water supply. Refer to Section 4.2 for more details.

\subsection{Introduction of foreign species, e.g. eel, silver carp, etc.}

Foreign fish species were introduced into Lake Balaton intentionally. First eel (Anguilla anguilla) was stocked beginning with 1961 for economic purposes. Planktivorous silver carp (Hypophthalmichthys molitrix, Hypophthalmichthys nobilis) was introduced from 1973 to "control planktonic eutrophication" (Szári, Zs., 2013). The results were as follows: Massive kills of eel, excessive dependence of the fishing industry on eel catch/exports, disturbances in the food web and decrease in the population of indigenous die of age in large numbers.

Unintentional introduction of foreign species also occurred in the $20^{\text {th }}$ century. Zebra mussel (Dreissena polymorpha) and a Ponto-Caspian amphipod (Corophium curvispinum) were introduced to Lake Balaton by a barge towed up from the Danube through the Sió Canal. Both are invasive species, and good filters of phytoplankton. Zebra mussel causes trouble by sticking to and clogging water withdrawal equipment, boats, piers, etc. (Fig. 12). Other foreign and invasive species introduced unintentionally include shellfish, algae and plant species.

\subsection{Agricultural land fragmentation through re-privatization}

After the political changes in 1990, the lands "nationalized" by the communist state was re-privatized, i.e. was partially returned to their rightful owners in a rather awkward scheme. This resulted in the subdivision of arable land, forests and vineyards into small plots of private owners. In this way the cultivation of land became very difficult and many of the plots were abandoned or inappropriate cultivation practices were used. This resulted in the increase of the spread of harmful weed species such as ragweed (Ambrosia artemisiifolia) and goldenrod (Solidago canadensis) and soil erosion (NÉBIH (2019).

\section{Summary of human interventions of adverse impacts}

The measures described above resulted in the loss of more than half of the volume and some $30 \%$ of the area of Lake Balaton as well as ca. $300 \mathrm{~km}^{2}$ of wetlands; loss of almost 
$70 \%$ of natural and semi-natural shoreline; interfered with the self-purification capacity of the lake; increased nutrient and pollutant load to surface and groundwater resources; reduced habitat and spawning area for aquatic species; caused several fish kills and interfered with the food web of Lake Balaton.

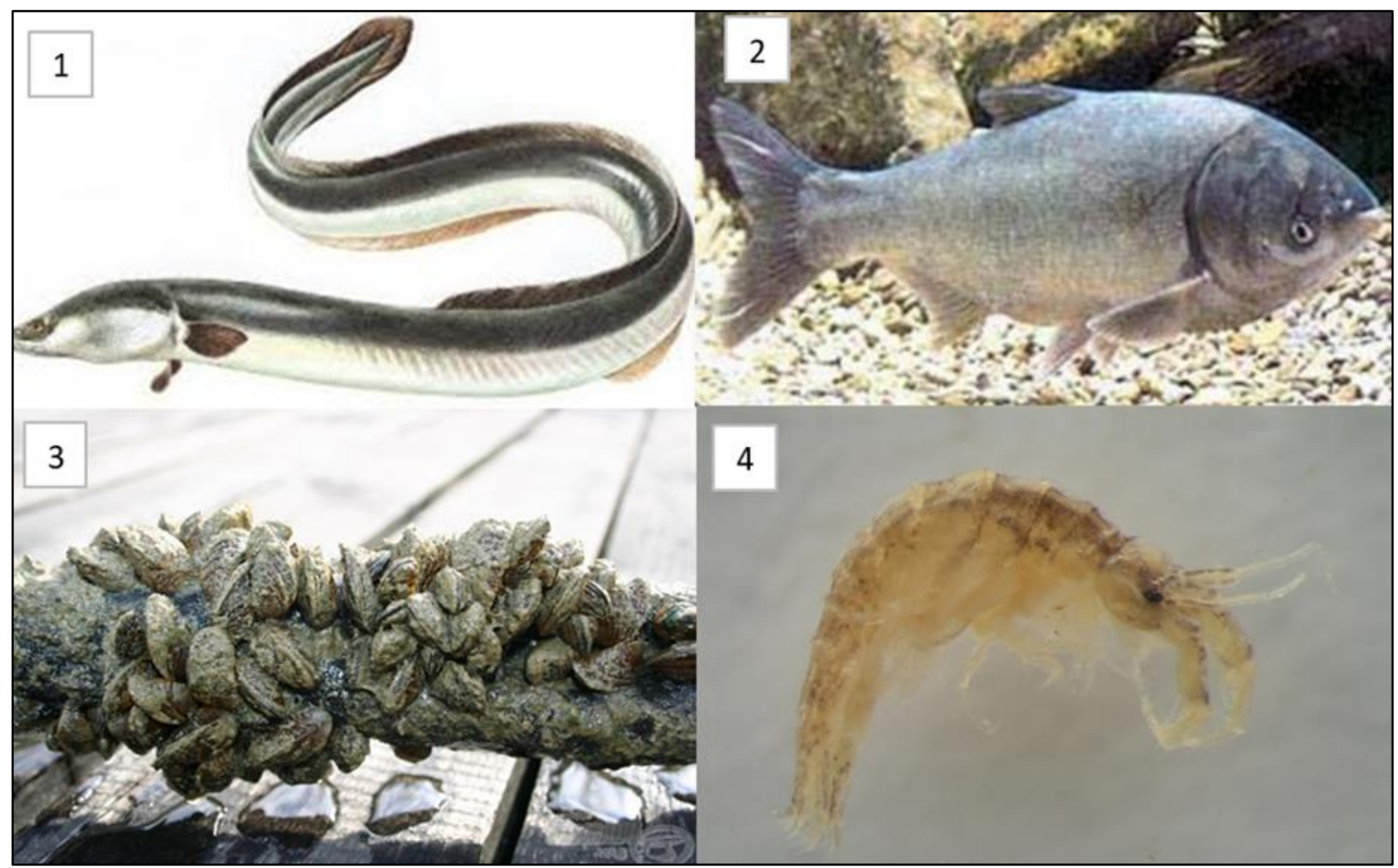

Figure 12. Some examples of foreign and /or invasive species in Lake Balaton (1-Anguilla Anguilla, 2 - Hypophthalmichthys nobilis, 3 -Dreissena polymorpha, 4 - Corophium curvispinum) (Source: 1,2,3 - www.haldorado.hu; 4 - www.europeana.eu)

Some of the interventions (or the lack of appropriate regulations) created a built environment that resulted in irreversible changes on the environment of Lake Balaton. Adverse changes in water quality have been experienced since the 1960s. Sebestyén (1958) and Vörös (1988) studied the amount of algae. Some of their results are summarized in Fig. 13. While the concentration of algal cells reported by Sebestyén (1958) was in the order of 104 to 105 cells/L during the 1947-1951 period, it increased by a factor of 10,000 in 3 decades.

All the above described human interventions resulted in an increase of nutrient (phosphorus, nitrogen) load to the lake. In Figure 14, nutrient concentrations of total phosphorus (TP), phosphate phosphorus (PO4-P) and total nitrogen (TN) in Zala river a few $\mathrm{km}$ from the river mouth are shown from the start date of systematic water quality monitoring to the time when full-blown eutrophication was observed. The large number of data scatters considerably, but the statistics in Table 4 clearly show the increasing trends in nutrient concentrations. (Mean and SD values are $\mathrm{mg} / \mathrm{m}^{3}$ for phosphorus, and $\mathrm{g} / \mathrm{m}^{3}$ for $\mathrm{TN}$.)
Though implementation of water quality control measures started in 1983, the deterioration of water quality of the lake culminated in the period from 1984 to 1994 . Mass killing of the eel population occurred in 1991 (and a less serious event in the subsequent year) and the largest bloom of blue-green

4

algae (Cylindrospermopsis raciborskii) took place in August 1994, when the entire lake turned hypertrophic as the data of the Lake Balaton water quality monitoring system indicated and shown in Fig. 23. (KDT KÖFE, 1994)

\begin{tabular}{|c|c|c|c|c|}
\hline Description & Symbol & TN & PO4-P & TP \\
\hline $\begin{array}{c}\text { Number of data } \\
\text { points }\end{array}$ & $\mathrm{N}$ & 472 & 612 & 470 \\
\hline $\begin{array}{c}\text { Correlation } \\
\text { coefficient of } \\
\text { linear trendline }\end{array}$ & $\mathrm{r}$ & 0.2170 & 0.2998 & 0.4205 \\
\hline $\begin{array}{c}\text { Pearson } \\
\text { significance } \\
\text { level test result }\end{array}$ & $\mathrm{p}<$ & 0.00001 & 0.00001 & 0.00001 \\
\hline Mean value & Mean & 4.59 & 244 & 558 \\
\hline $\begin{array}{c}\text { Standard } \\
\text { deviation }\end{array}$ & $\mathrm{SD}$ & 1.96 & 184 & 323 \\
\hline
\end{tabular}

Table 4. Statistics for observed nutrient concentrations in Zala river at Zalaapáti village (Analysis by the author based on raw monitoring data of KDT KÖFE) 
Increase in the annual monthly maximum* number of algae cells in the water of Lake Balaton (based on Sebestyén, 1958 and Vörös, 1986)

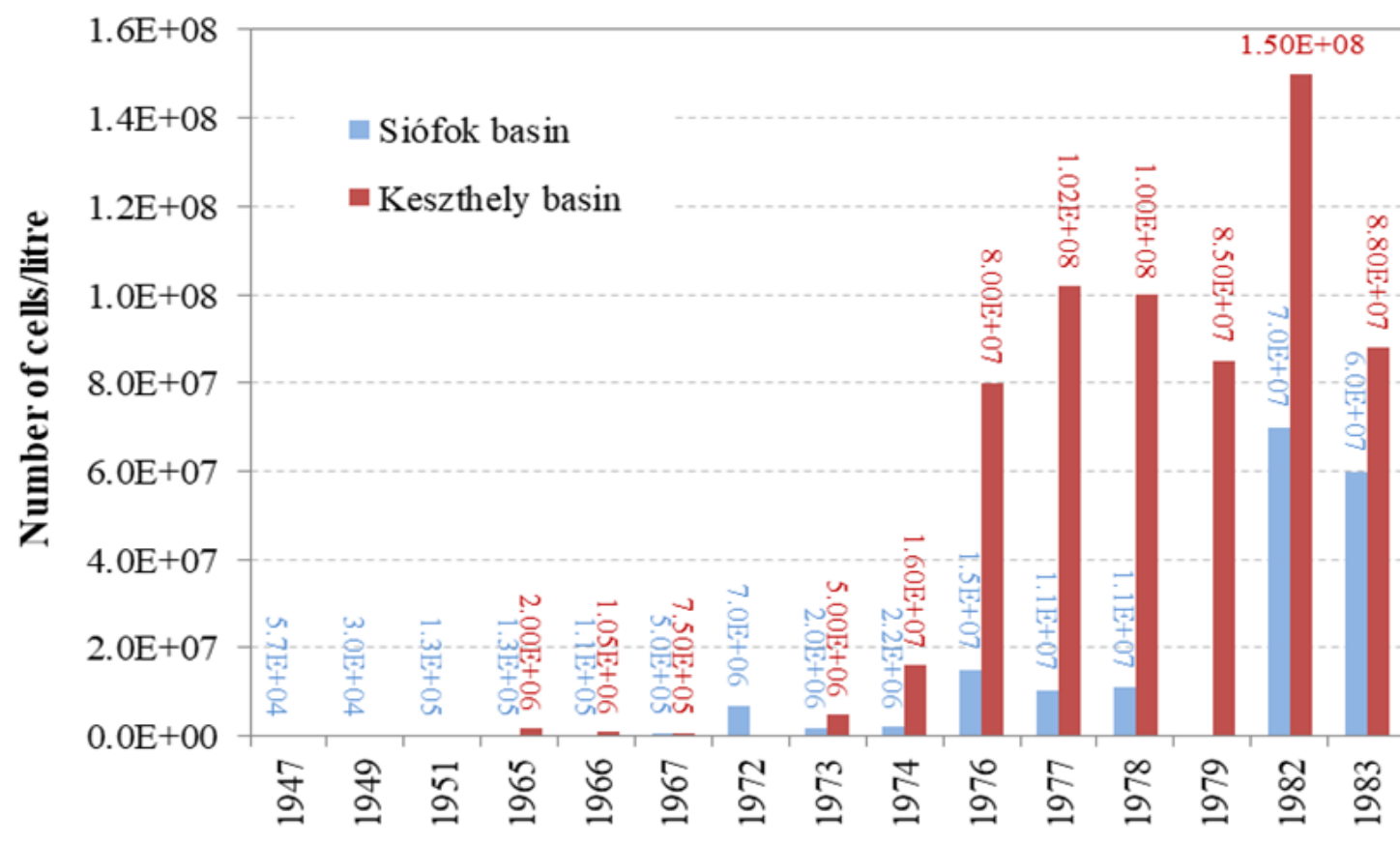

Year AD.

Figure 13. Changes in the concentration of phytoplankton cells in Lake Balaton $(*$ for the 1949-1951 period summer half-year maximums are shown)

Zala River Zalaapáti

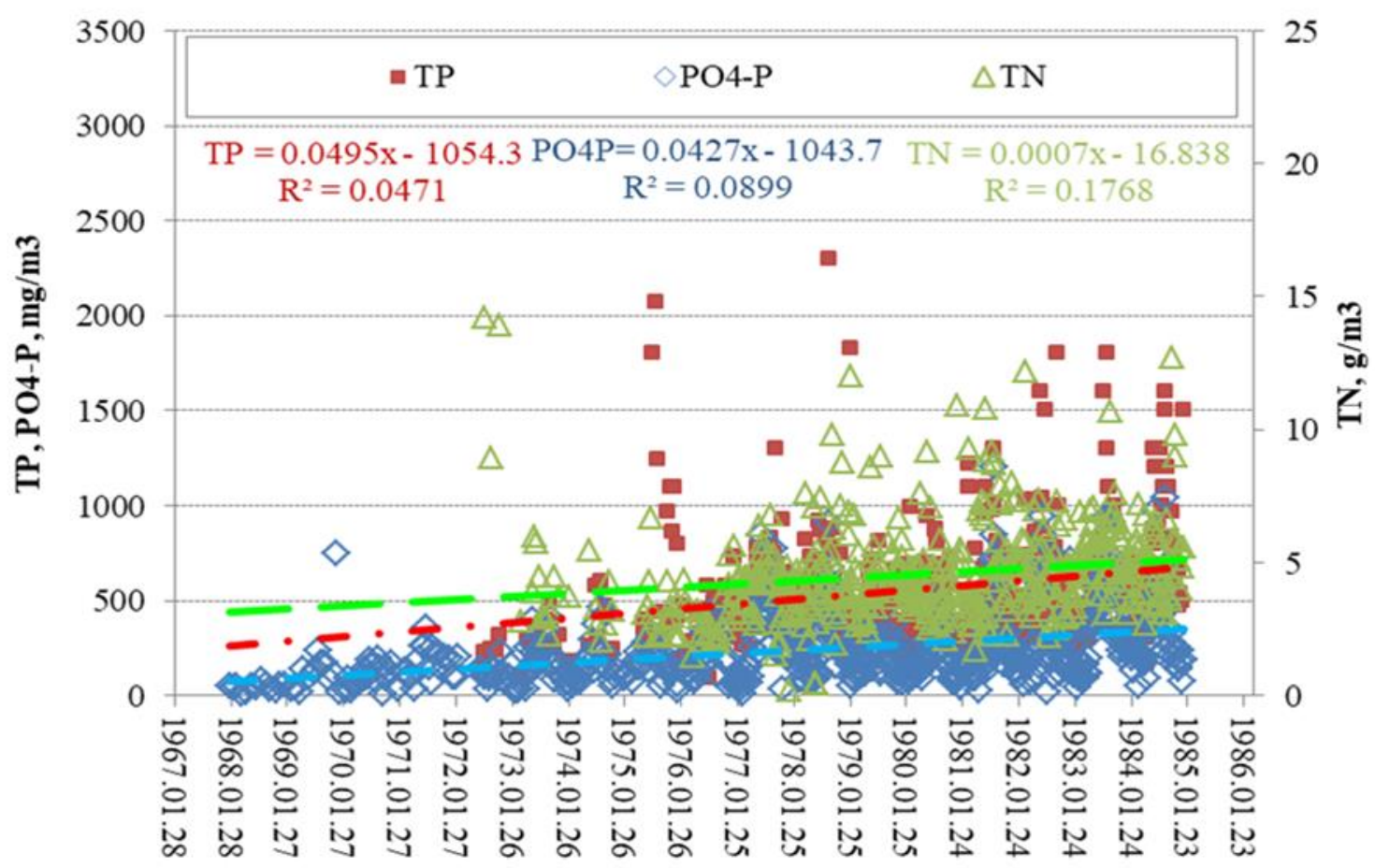

Figure 14. Trends in nutrient concentrations in Zala river at the standard water quality monitoring point in the village of Zalaapáti during the period of the development of eutrophication (Analysis by the author based on raw monitoring data of KDT KÖFE) 


\section{Human interventions with mostly positive impact on the Lake Balaton environment}

After decades or even centuries of mostly detrimental interventions in the environment of Lake Balaton, need for interventions to improve water quality and the environmental conditions of the lake and its surroundings was recognized, and several measures were implemented. The most important ones are as follows:

1) Restoration of the Kis-Balaton wetlands

2) Development of the sewer system and sewage treatment around the lake

3) Introduction of phosphorus precipitation and stricter effluent $\mathrm{P}$ standards at sewer treatment plants

4) Diversion of treated STP effluents to other watersheds

5) Banning of liquid manure technologies at livestock breeding farms on the watershed

6) Dredging of the most polluted Keszthely basin

7) Reduction of the use of fertilizers on the watershed

\subsection{Restoration of the Kis-Balaton wetlands}

Described in Section 2, the vast wetlands along the downstream section of River Zala were drained and the original habitat destroyed. The sedimentation and filtering function of the wetland was eliminated resulting in fast siltation and eutrophication of the Keszthely Basin. By the end of the 1970s, scientists recognized the need to restore (or rather, construct a new wetland, since the original conditions could not be reproduced) Kis-Balaton (Herodek S. et al., 1988). Immediate planning started. The original, mechanistic plan (with little consideration of ecological aspects or sustainable operation) consisted of Stage I (upper lake of 18 $\mathrm{km}^{2}$, and 1.16 mean water depth) and Stage II (lower lake of $51 \mathrm{~km}^{2}$ and $1.25 \mathrm{~m}$ mean water depth). Stage I would serve as a sedimentation basin and conversion of dissolved phosphorus (DP) to particulate P (i.e. algae) and Stage II as a "filter" of algae with huge reed stands. Stage I was inundated in 1985. Due to lack of finances and concerns about the credibility of the operational hypothesis, only a $16 \mathrm{~km}^{2}$ part (Stage II/1) of Stage II was inundated in 1992. A long debate and several re-designs of Stage II followed, resulting in a huge delay in the implementation. Eventually, Stage II was finished at the end of 2014, with significant modifications of the original plan (www.nyuduvizig.hu) . The modifications include the separation of Stage II/1 from the other water bodies and assigning priority to nature preservation functions, reconstruction of the short-cut possibility of River Zala, and considerably lower water levels in the rest of the Stage II area (Stage II/2). In spite of the delays in implementation and changed priorities of its function (i.e. nature conservation over water quality improvement of Lake Balaton) the reconstructed wetland removed $81 \%$ of suspended solids, $37 \%$ of total phosphorus and $42 \%$ of total nitrogen during the 1993-2006 period as compared to the average values of the 1976-1985 period (www.nyuduvizig.hu).

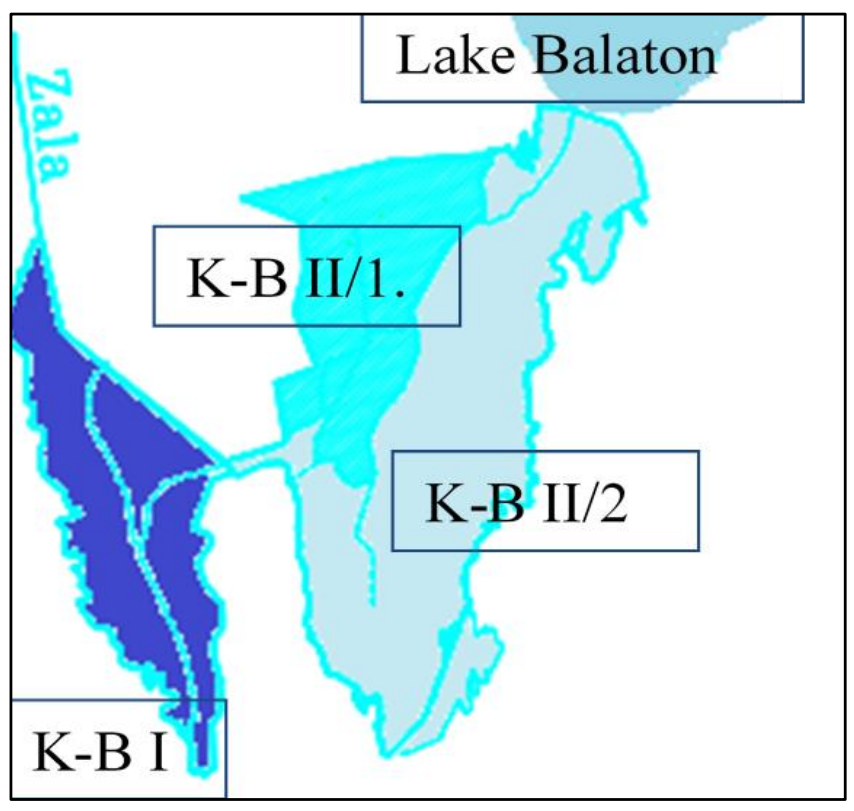

Figure 15. Zala river and the Stages of the Kis-Balaton reconstructed wetlands at the SW end of Lake Balaton (based on http://www.nyuduvizig.hu/index.php/vizrajz/kis-balatontavmero-rendszer-vizmerleg)

\subsection{Development of the sewer system and sewage treatment}

The urgent need for sewer and sewage treatment development was recognized at the end of the 1970s and efforts were made to reduce the gap between the availability of drinking water supply and sewer system. However, the lack of financial resources in the last decade of the ailing communist system resulted in delays in sewer development and significant advances were achieved only after 1990. The direct phosphorus load of sewage origin to Lake Balaton was reduced from 32 tons/year in the $1975-1979$ period to about 1 ton/year after 2000 (Kutics, K., 2011). The sewer connection ratio (No. of households connected to sewer system $\div$ No. of households connected to drinking water supply $x$ 100) in shoreline municipalities has reached $95 \%$ in recent years (Fig. 16). Some of the small villages, especially on the Southern part of the watershed are still waiting for sewer connections. Some of the villages engaged in local, individual (single households) solutions for sewage treatment and effluent disposal (by infiltration).

\subsection{Introduction of phosphorus precipitation and stricter effluent $P$ standards at sewer treatment plants $(T P<0.7 \mathrm{mg} / \mathrm{L})$}

Legislation on the protection of surface waters ("28/2004. (XII. 25.) KvVM rendelet", i.e. ordinance of the Ministry of Environmental Protection and Water as well as predecessors of this piece of legislation) places Lake Balaton watershed into a separate special category of protection for which the effluent standards are stricter than for the rest of the country. Phosphorus precipitation at sewage and industrial wastewater treatment plants is compulsory, and the total phosphorus effluent standard is $0.7 \mathrm{mg} / \mathrm{L}$ for those plants that discharge treated effluents to Lake Balaton or to its tributaries. For nutrient species the effluent limits are only $20 \%$ of areas 
under general protection and $42 \%$ of areas under special protection. as shown by the water quality monitoring data of e.g. Zala river (Fig. 20).

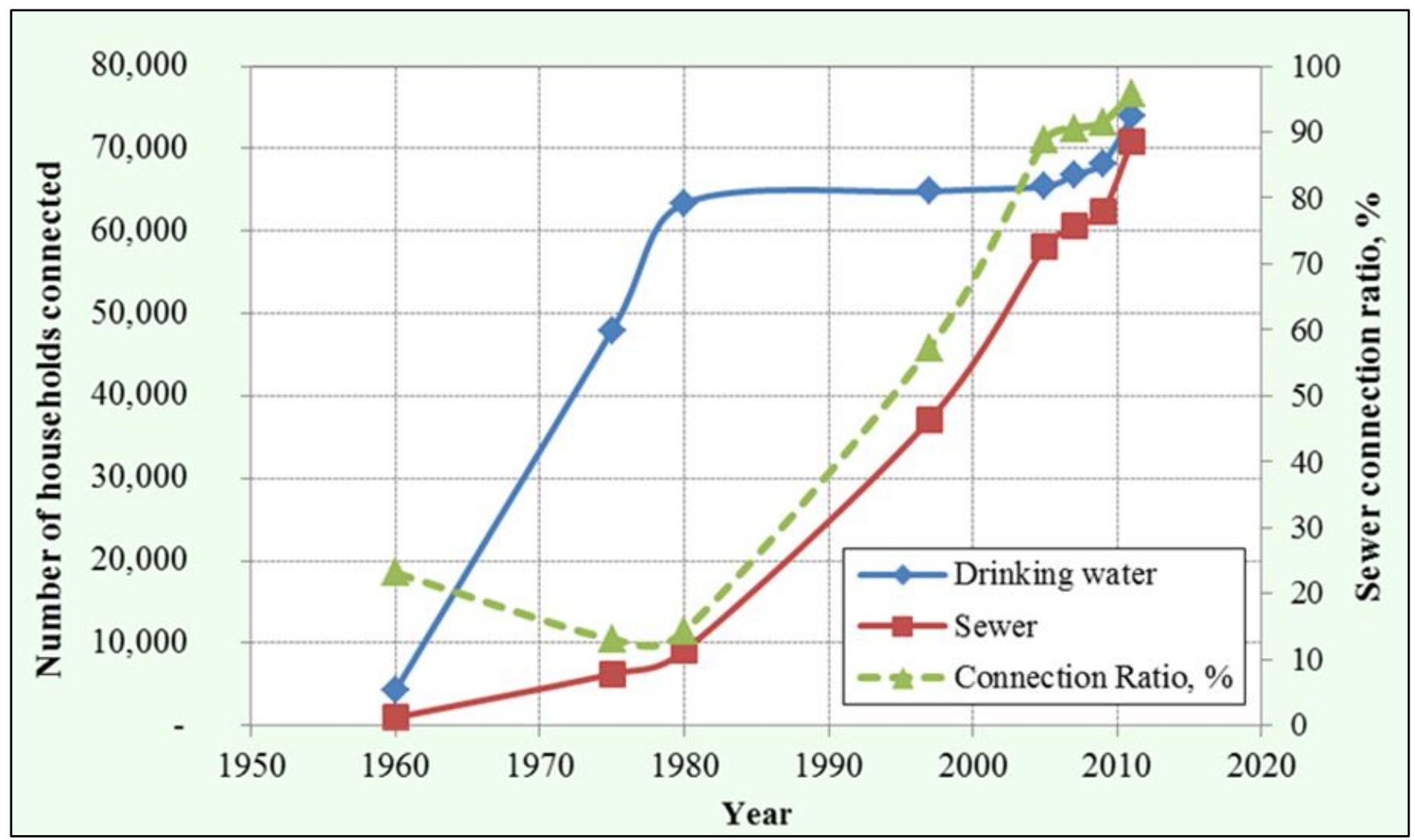

Figure 16. Evolution of drinking water and sewer connection of households as well as the sewer connection ratio in the lakeshore communities of Lake Balaton (Processed data of Koltay J., 2001 and KSH, 2013)

This intervention contributed to the reduction of nutrient load to Lake Balaton (Jolánkai G., 2007).

\subsection{Diversion of treated STP effluents to other watersheds}

It was recognized at the beginning of the 1980s that with prospective sewer development the amount of effluents would increase. To prevent the increase of nutrient load of sewage origin as well as to reduce the risks constituted by treatment plant failures or malfunctions, a large portion of sewage treatment effluents are discharged to other watersheds (i.e. diverted from the Lake Balaton watershed). Sewer mains of several tens of miles were constructed and the transferred sewage is treated in a few STPs and eventually discharged to small rivers outside of the Lake Balaton Watershed (Fig. 17, Kutics K., 2015, base map: www.drv.hu).

\subsection{Banning of liquid manure technologies at livestock breeding farms on the watershed}

Liquid manure technology used widely at large, state controlled/owned livestock breeding facilities was banned by a Government Ordinance in 1983. This measure was intended to reduce external nutrient load to the lake since liquid manure treatment or utilization hardly existed. The measure contributed to the reduction of nitrogen and biologically available phosphorus load to the tributaries of Lake Balaton
Changes in the number of livestock also helped in the reduction of the problem (though it was harmful for the national economy). The number of cattle, swine and sheep was reduced by $60 \%, 69 \%$, and $61 \%$, respectively in the 1985 -2013 period.

\subsection{Dredging of the most polluted Keszthely basin}

Because of the "short cut" of River Zala through the former wetland "Kis-Balaton" (Balaton Minor), siltation of the westernmost basin (Keszthely basin) of the lake accelerated. In addition, due to the increased nutrient load in the second half of the $20^{\text {th }}$ century, a lot of phosphorus accumulated in the sediment. Dredging started experimentally in 1979 and picked up pace after 1989 (Fig. 18). Although a plan existed to dredge the whole surface of Keszthely basin $\left(38 \mathrm{~km}^{2}\right)$, later it was modified mostly due to financial problems. Nevertheless, the most polluted $11.6 \mathrm{~km}^{2}$ of the sediment was dredged. The total dredged volume was 5.55 million $\mathrm{m}^{3}$ with an average depth of dredging being $32 \mathrm{~cm}$. Total phosphorus removed is estimated to be 2050 tons, corresponding to about 20 year of external TP load of the basin (Kutics K., 2015).

4.7. Reduction of the use of fertilizers on the watershed - a "spontaneous measure" due to re-privatization of land

As it was pointed out in section 3.5, fertilizer use was excessive in the period from 1960 to 1989 . Political changes 


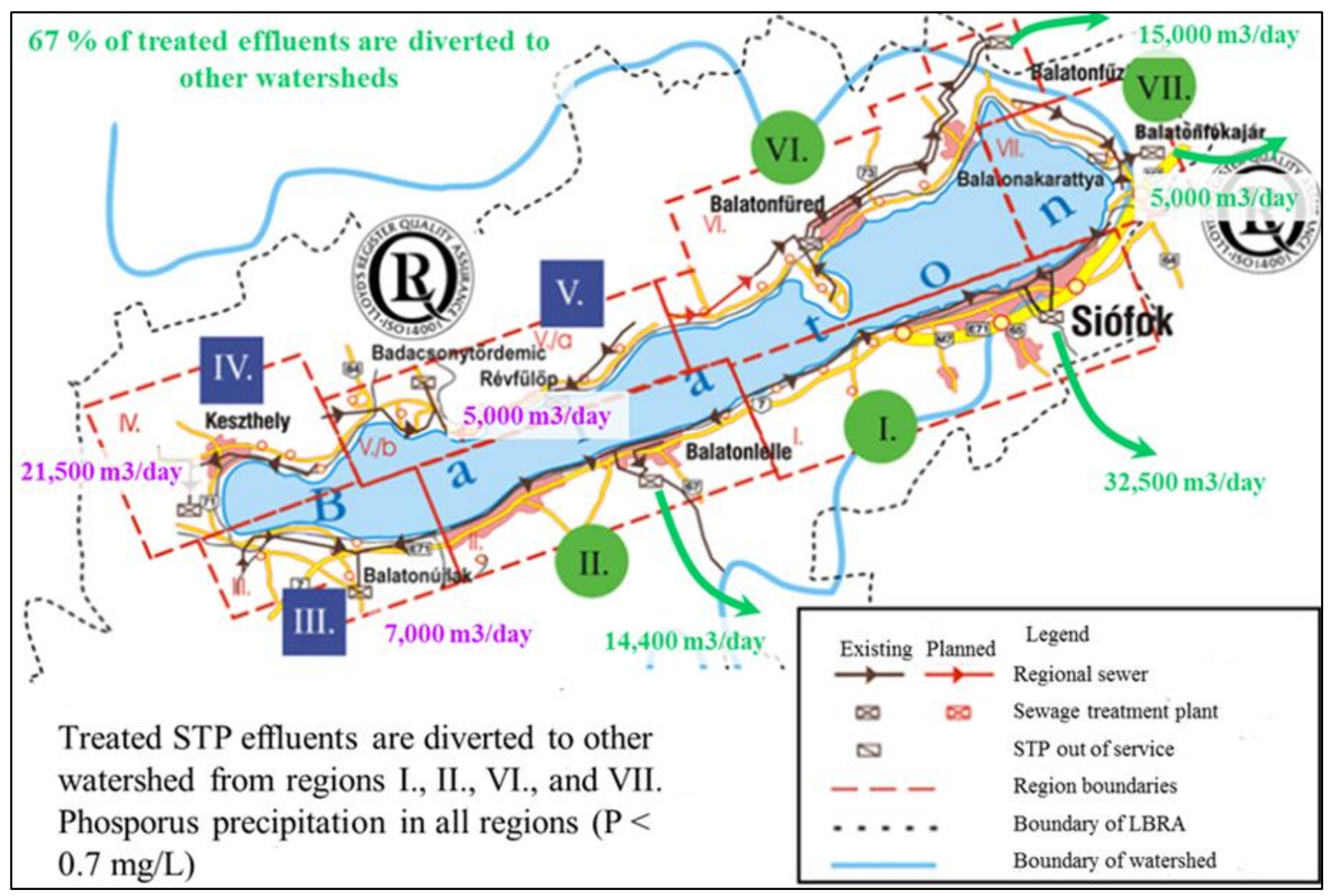

Figure 17. Sewage collection regions of Lake Balaton - Green arrows show diversion of treated effluents to other watersheds (base map is from the Transdanubian Regional Water Works, www.drv.hu)

in the cutting of subsidies of state-controlled farms and reprivatization of land created a large number of old-new owners without resources to buy fertilizers. The annual average use of NPK fertilizers from 1960 to 2008 of the three counties around the lake is shown in Figure 19. It is clear that the drop of fertilizer usage from about $220 \mathrm{~kg} / \mathrm{ha} / \mathrm{y}$ to about $35 \mathrm{~kg} / \mathrm{ha} / \mathrm{y}$ did not result in significant drop in the yields of wheat and sunflower (and neither in case of corn -not shown here) (Ref. to Fig. 19 for sources). Linear regression analysis between fertilizer use and crop yield for the whole period resulted in the equations as follows: wheat: $\mathrm{y}=0.0017 \mathrm{x}+$ $3.897\left(\mathrm{R}^{2}=0.0297\right)$; sunflower: $\mathrm{y}=-0.0008 \mathrm{x}+1.9165\left(\mathrm{R}^{2}=\right.$ 0.0264 ), i.e. no significant trends were revealed. ( Crop yield changes cannot be explained by the used amount of fertilizers. Rather, other factors, most probably meteorological conditions and the cultivars used play key role. It seems that the amount of fertilizers applied in the last 10 year shown in the figure is enough to maintain (or even slightly increase) the high yields (Fig. 19). The difference of over-fertilization (1975-1985 average) and "normal" fertilization (1999-2008 average) is $157.1 \mathrm{~kg} / \mathrm{ha} / \mathrm{y}$. Taking into account the agricultural land (without pasture and meadow) (Kertész, 2011 and Szilassy, 2007), the fertilized land area is 217,644 ha, and the excess of fertilizers in the $1975-1985$ period amounts to as much as 342,000 tons (for reference, the multiannual $\mathrm{N}+\mathrm{P}$ load of Lake Balaton in the last 10 years of study are about $2,603+154 \mathrm{t} /$ year (Kutics, 2011). The radical drop in the amount of fertilizers used played an important role in the recent improvement of surface water quality in the Lake Balaton Watershed.

\section{Results of interventions to improve the environmental conditions of Lake Balaton}

The efforts made in the form of interventions and measures resulted in a significant reduction in the nutrient load (especially phosphorus, the limiting nutrient) and the load of sediment and other pollutants. The estimated total phosphorus (TP) load was $327 \mathrm{t} /$ year in the last 5 years before the interventions (average of the 1975-1979 period) while it was reduced to an average of $154 \mathrm{t} /$ year in the 1997-2006 period. Figure 20 is similar to Figure 14, but it shows the changes in the nutrient concentrations of Zala river during the implementation of nutrient load reduction measures.

The direct sewage related TP load was almost completely eliminated, and the TP discharged by the tributaries into the lake was reduced to $30 \%$ of its baseline value. However, nutrient and other pollutant load from direct runoff are still problems to deal with (Fig. 21). Also, after the initial years of load reduction measures that resulted in considerable drop in nutrient loads, a slowdown is experienced. In Figure 22 total phosphorus load is shown after 1986. Due to the problems of the monitoring system discussed later in Section 6.1 , conventional load calculation was stopped in 2007 since monitoring data was not sufficient to apply the usual methodology. 


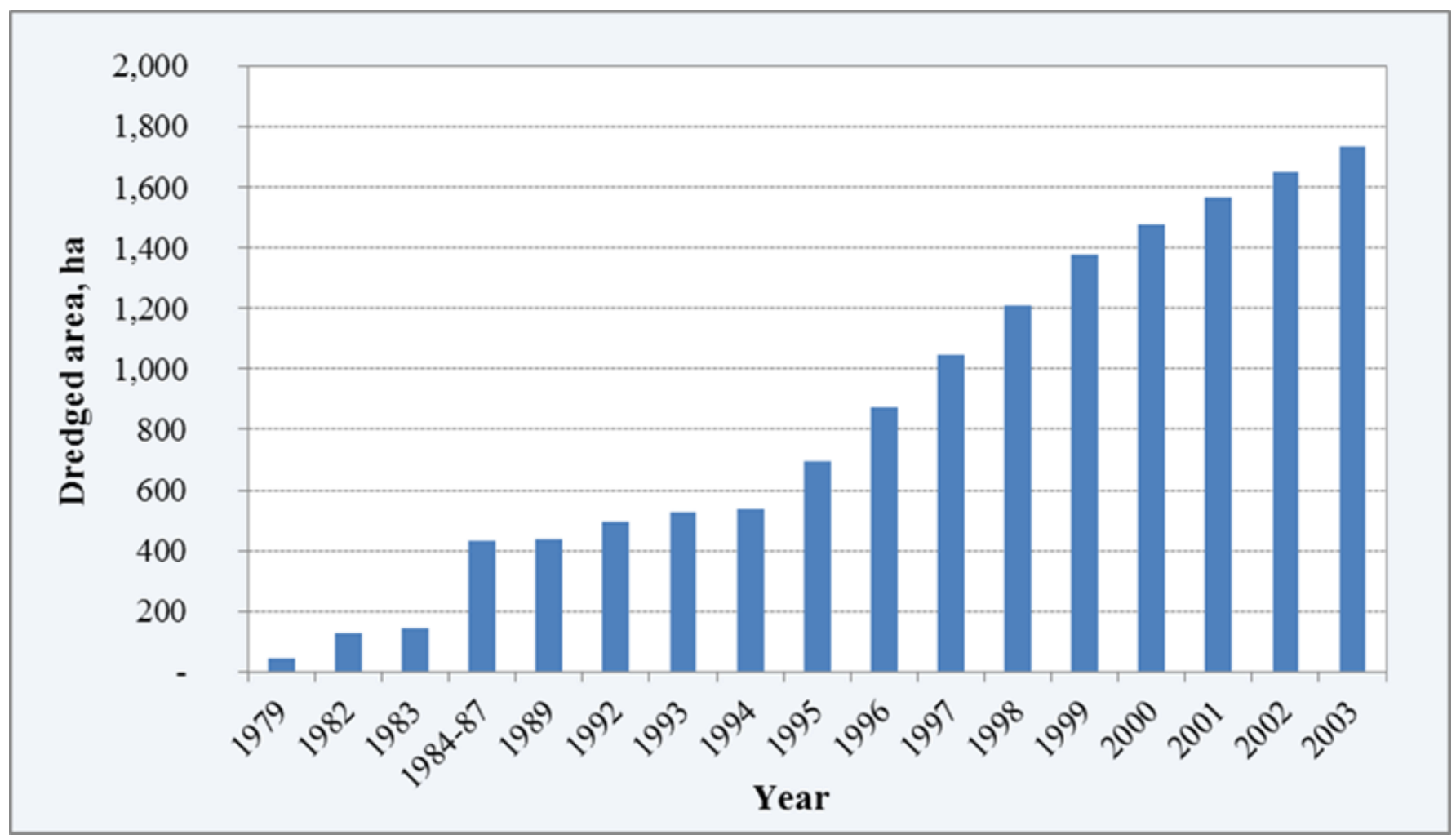

Figure 18. Cumulative lake area where sediment was dredged in the Keszthely Basin of Lake Balaton (Source: Papp F., 2005)

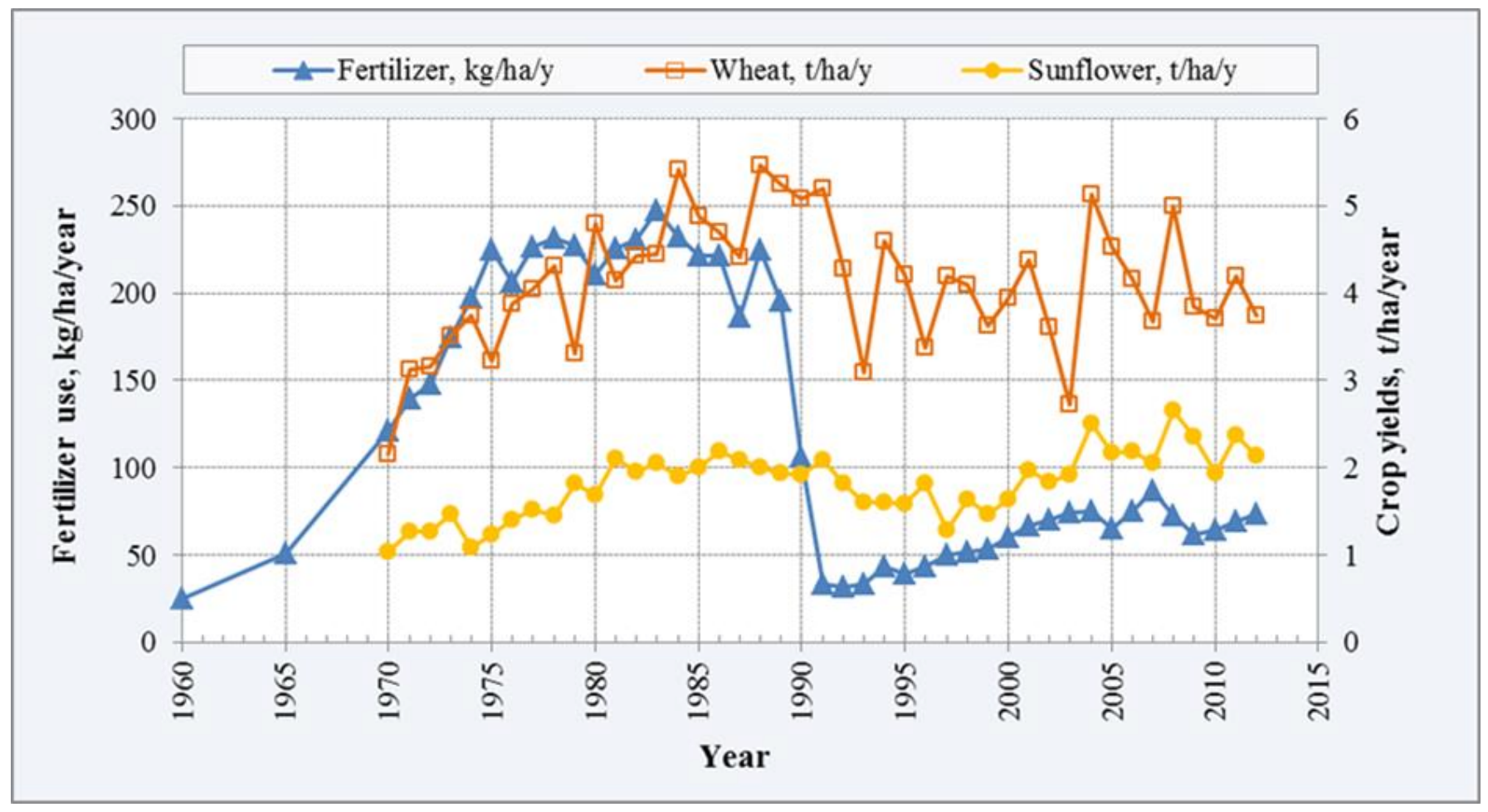

Figure 19. Change in the use of fertilizers (as NPK) and yields of wheat and sunflower crops (Reprocessed data of Pálmay, O., 2010, Lencsés E., 2013 and KSH, 2013.) 


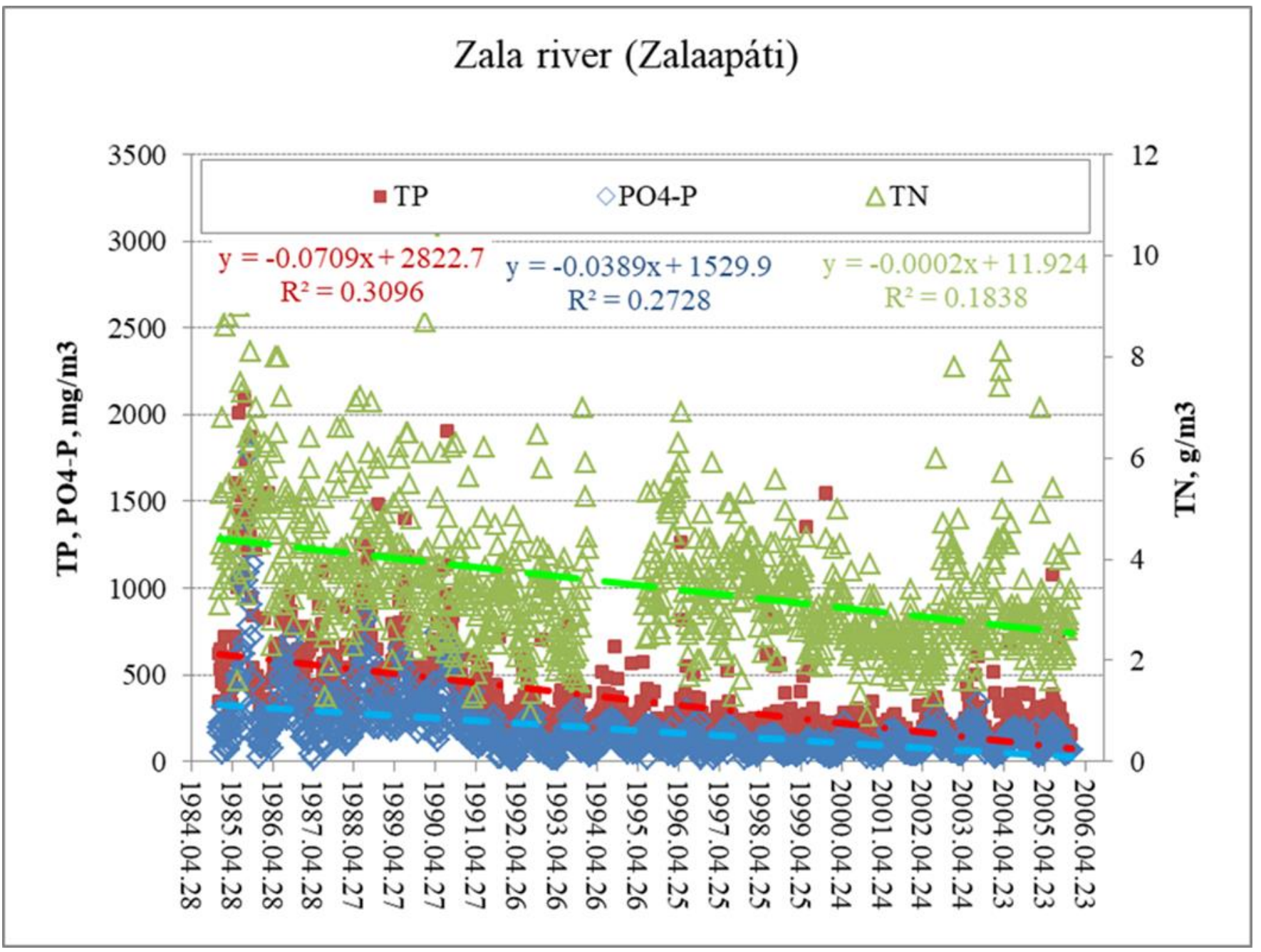

Figure 20. Trends in nutrient concentrations in Zala river at the standard water quality monitoring point in the village of Zalaapáti during the period of the implementation of WQ control measures.

\begin{tabular}{|l|l|l|l|l|}
\hline Description & Symbol & TN & PO4-P & TP \\
\hline $\begin{array}{l}\text { Number of data } \\
\text { points }\end{array}$ & $\mathrm{N}$ & 987 & 1061 & 1060 \\
\hline $\begin{array}{l}\text { Correlation } \\
\text { coefficient of } \\
\text { linear trendline }\end{array}$ & $\mathrm{r}$ & 0.5551 & 0.5223 & 0.4287 \\
\hline $\begin{array}{l}\text { Pearson } \\
\text { significance } \\
\text { level test result }\end{array}$ & $\mathrm{p}<$ & 0.00001 & 0.00001 & 0.00001 \\
\hline Mean value & Mean & 3.47 & 174 & 349 \\
\hline
\end{tabular}

Table 5. Statistics for observed nutrient concentrations in Zala river at Zalaapáti village during the implementation of WQ control measures (Analysis by the author based on raw monitoring data of KDT KÖFE, from 1984 to 2006)

An effort by KDT VIZIG was done in 2016 by using their own extra monitoring data, but 9 years are missing in the time series. We applied a new estimation by establishing a correlation between annual inflow volume and TP load. The obtained equation is TP load $=-8.3664 \mathrm{E}-05^{*}$ Inflow $2+$ $2.7996 \mathrm{E}-01 *$ Inflow $+7.4306 \mathrm{E}+00$, with $\mathrm{R}^{2}=0.92169$. The correlation is significant at $\mathrm{p}=0.0001$ level. By applying this equation, TP loads for the missing years were estimated. Figure 22 shows the data points of conventional estimation as well as the application of the new method for the whole period (blue line). The new estimates agree well with the data points, but the decreasing trend of both datasets is weak, and the correlations are not significant. This indicates that at present the TP load is rather a function of the meteorological conditions, i.e. precipitation and temperature that determines inflow. However, this dependence should be reduced through effective and efficient nutrient load control measures.

As a result of former TP load reduction interventions, eutrophication of the lake was stopped and even reversed. Years after 1994 showed significant reduction in algal biomass (in terms of chlorophyll-a), as shown in Figure 23 and Figure 24. The trophic status of all the 4 basins of the lake improved significantly and hypertrophic conditions were almost completely eliminated. However, a dry spell from year 2000 to 2003 with extreme drought and very low lake levels (some $24 \%$ of lake volume was lost by the end of 2003) 
indicated the vulnerability of both the water balance and water quality.

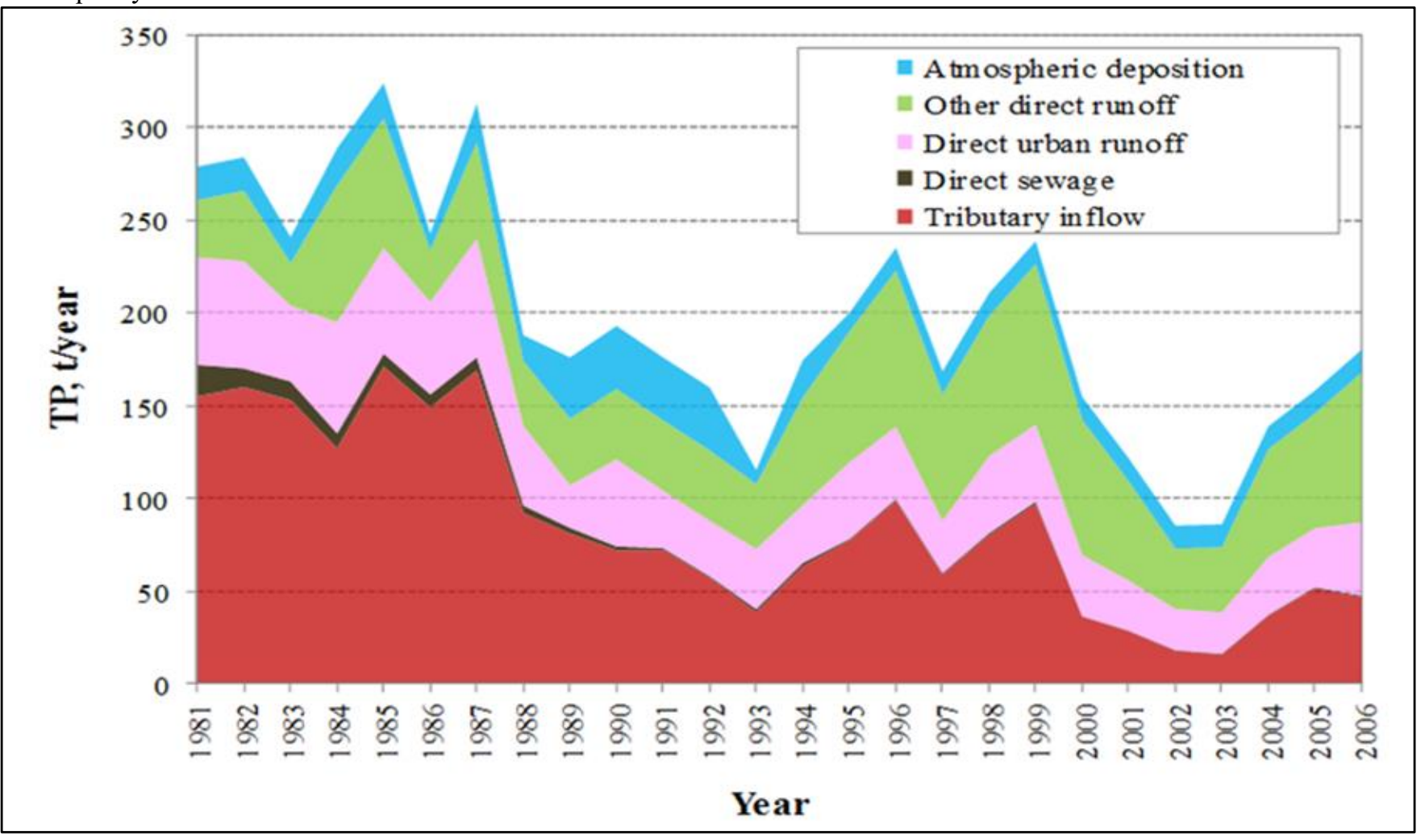

Figure 21. Change of total phosphorus load of Lake Balaton (after Jolánkai G., 2007 and Kutics K., 2011)

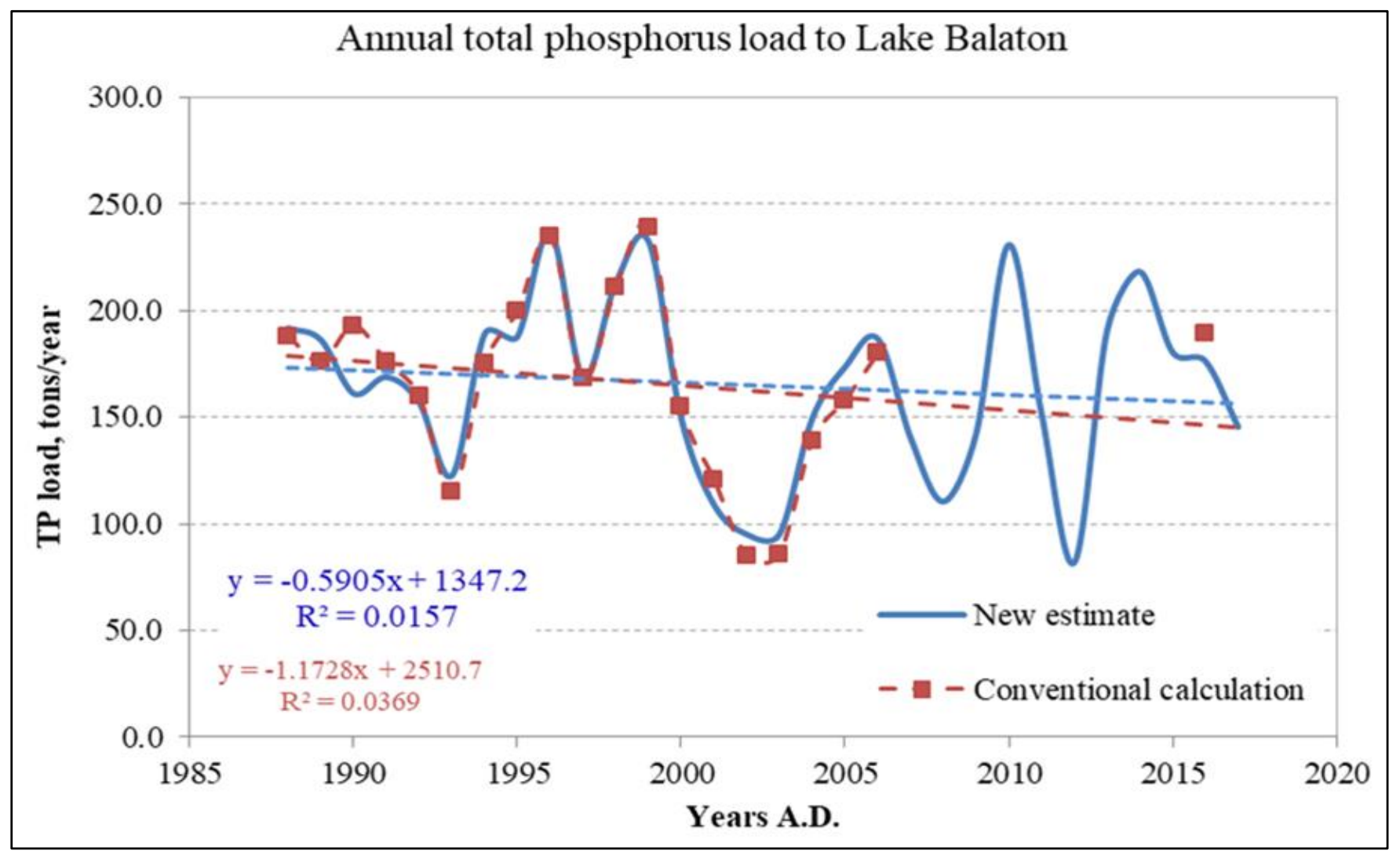

Figure 22. Recent trends in phosphorus load to Lake Balaton (Jolánkai, G. (2007) and author's own analysis of monitoring data) 
Lake Balaton, irreversible changes include the reduction of

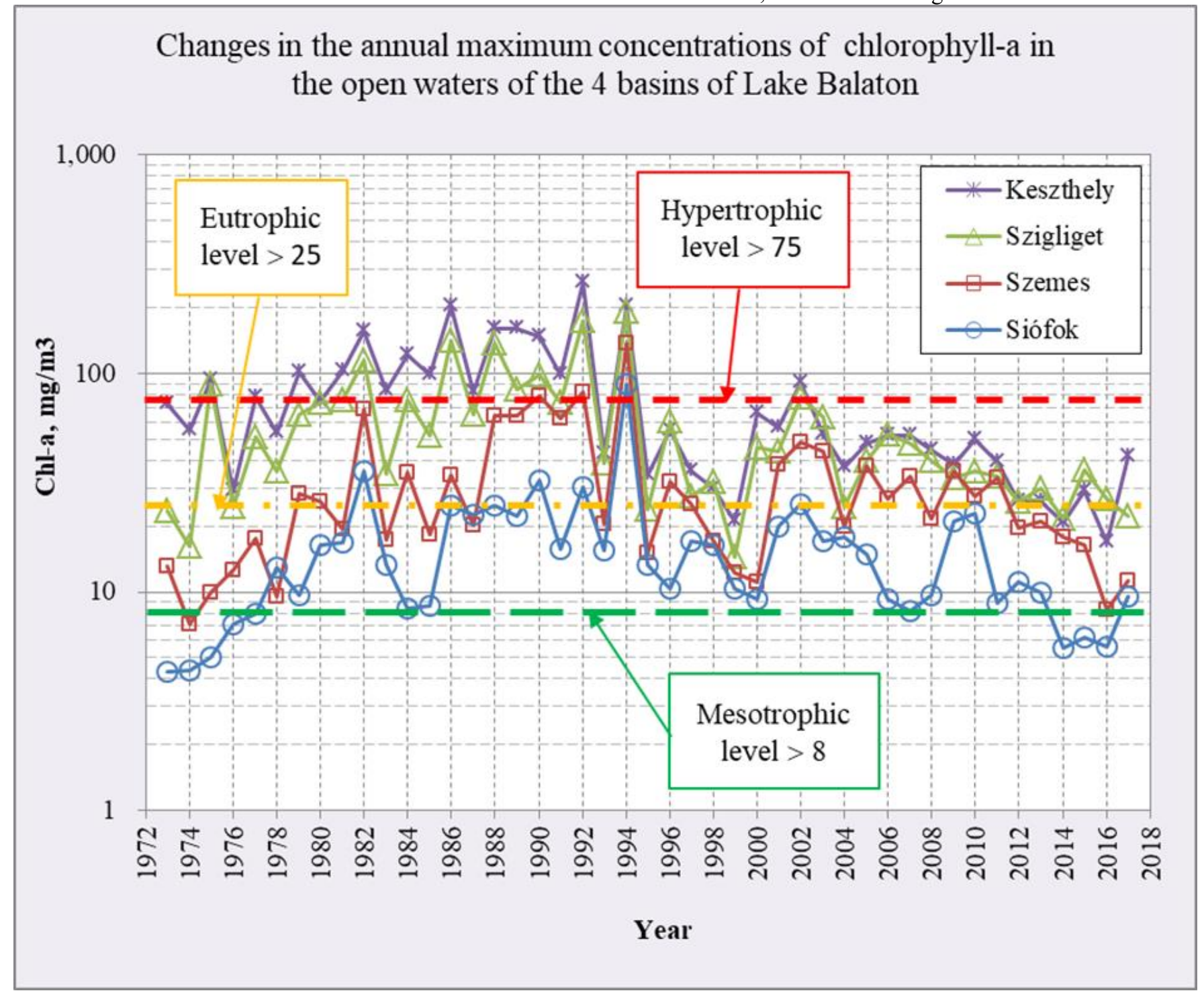

Figure 23. The time series of measured chlorophyll-a maximum concentrations in the four basins of Lake Balaton

Since climate change is expected to result in further deterioration of water balance and higher water temperatures, further efforts should be made to reduce the nutrient load from direct urban runoff and other non-point sources (Kutics, 2013). Bathing water quality is of utmost importance for Lake Balaton since hundreds of thousands of guests and local residents are bathing, swimming and doing other water sports activities in the lake from May to September. Bathing water quality (bacteria, algae, hazardous pollutants) is strictly monitored by the Public Health Authorities. An example of a water quality map of the several beaches is shown in figure 25. Bathing water quality is generally "excellent", only a few beaches drop into the "good" category. "Objectionable" category has not occurred since the massive algae bloom of 1994.

\section{Lessons}

Intervention in the natural environment of lakes, especially shallow ones of high vulnerability and low resilience may result in detrimental and often irreversible changes. In case of lake level and subsequent construction directly on the lake shore as well as introduction of foreign species such as eel and silver carp. Reasons for the negative results/impacts of the introduced interventions are: insufficient level of technical or scientific knowledge at the time of planning and implementation; poor decision support systems and mechanisms; insufficient consultation with local people and experts of other fields; lack of integrated approach, both in terms of territorial and interdisciplinary aspects; and pursuing of short term economic or political benefits.

Some of the negative impacts, however, can be reversed by concerted and targeted interventions and introduction of complex, ecosystem centred management systems where the ecological, social and economic carrying capacity of the target areas is taken into account in landscape conservation strategies (Némethy, 2019). Unfortunately, the costs and time requirement to implement such interventions may be excessive. Taking the example of Lake Balaton, eutrophication of the lake could be reversed and the 
environmental conditions in and around the lake could be improved through a number of costly interventions.

empowerment of local people, stakeholders and a diverse choice of experts are becoming basic requirements in environmental and spatial development policy; integrated approaches both in terms of territorial and interdisciplinary

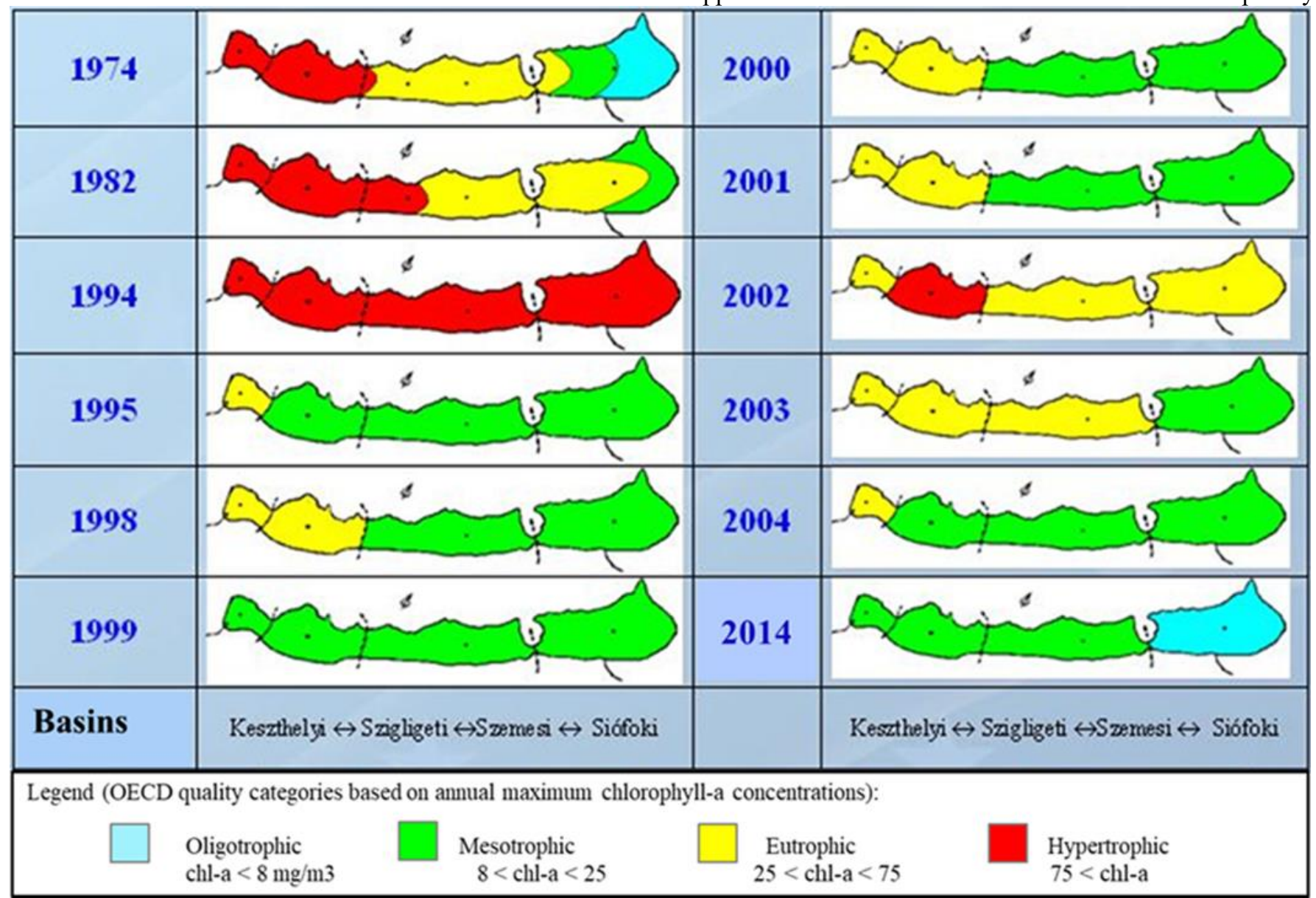

Figure 24. Trophic categories of the 4 basins of Lake Balaton based on annual maximum chlorophyll-a concentration (data source: KDT KÖFE and http://web.okir.hu/sse/?group=FEVISZ)

However, due to the irreversible impacts of detrimental interventions, the vulnerability of the lake to various pressures such as climate change, land use, and foreign or invasive species increased, and it cannot be reduced to the original (pre-intervention) level. Climate change is considered as a particularly serious issue (Varga \& Kravinszkaja, 2013, Kutics \& Molnár, 2013). Natural water budget (Precipitation + Inflow -Evaporation) was decreasing sharply in the last few decades while year-to-year changes are increasing. Negative balance never occurred before year 2000, but it was negative in 7 years since then. As Lake Balaton became an extremely shallow lake due to gradual water level (and volume) reduction through level control measures, it is more vulnerable to such changes as it would be without water level control.

Compared to the situation one and a half centuries ago, many of the reasons leading to adverse effects can be eliminated because: technical and scientific knowledge is increasing with high speed and huge amount of monitoring, etc. data are becoming available; decision support systems and mechanisms are getting faster and are improving in complexity; consultation with, participation, and aspects are gathering momentum.

It would be of great importance to stop pursuing short term economic gains and political benefits when significant interventions into lake environments are considered.

\section{New and emerging problems}

\subsection{Problems of the water quality monitoring system}

Lake Balaton is a rather well researched and monitored water body. Systematic observation and research of the lake started in 1891 by the well-known geologist Lajos Lóczy. Lake Balaton Limnological Research Institute situated in the Tihany peninsula was established in 1927. After recognition of the accelerated eutrophication of Lake Balaton, systematic, state sponsored monitoring stated in the 1960s. By the end of the 1970 s, practically all the tributaries were monitored in addition to the 11 in-lake monitoring points. Sediment monitoring was also part of the system since the importance of internal nutrient load was recognized.

After EU accession, the monitoring system was adjusted to the EU-WFD requirements. This resulted in a large-scale reduction of monitoring points and sampling frequency. 
Sediment monitoring was completely stopped. In Table 6 the main figures of the former and the new monitoring system are shown. It is beyond dispute that Lake Balaton came out badly from this reform. Altogether the water quality monitoring system was reduced to some $20 \%$ of its original size. exact evaluation of the efficiency of specific water quality control measures.

According to the present system there are a mere 7 surveillance monitoring points, 4 along the longitudinal axis

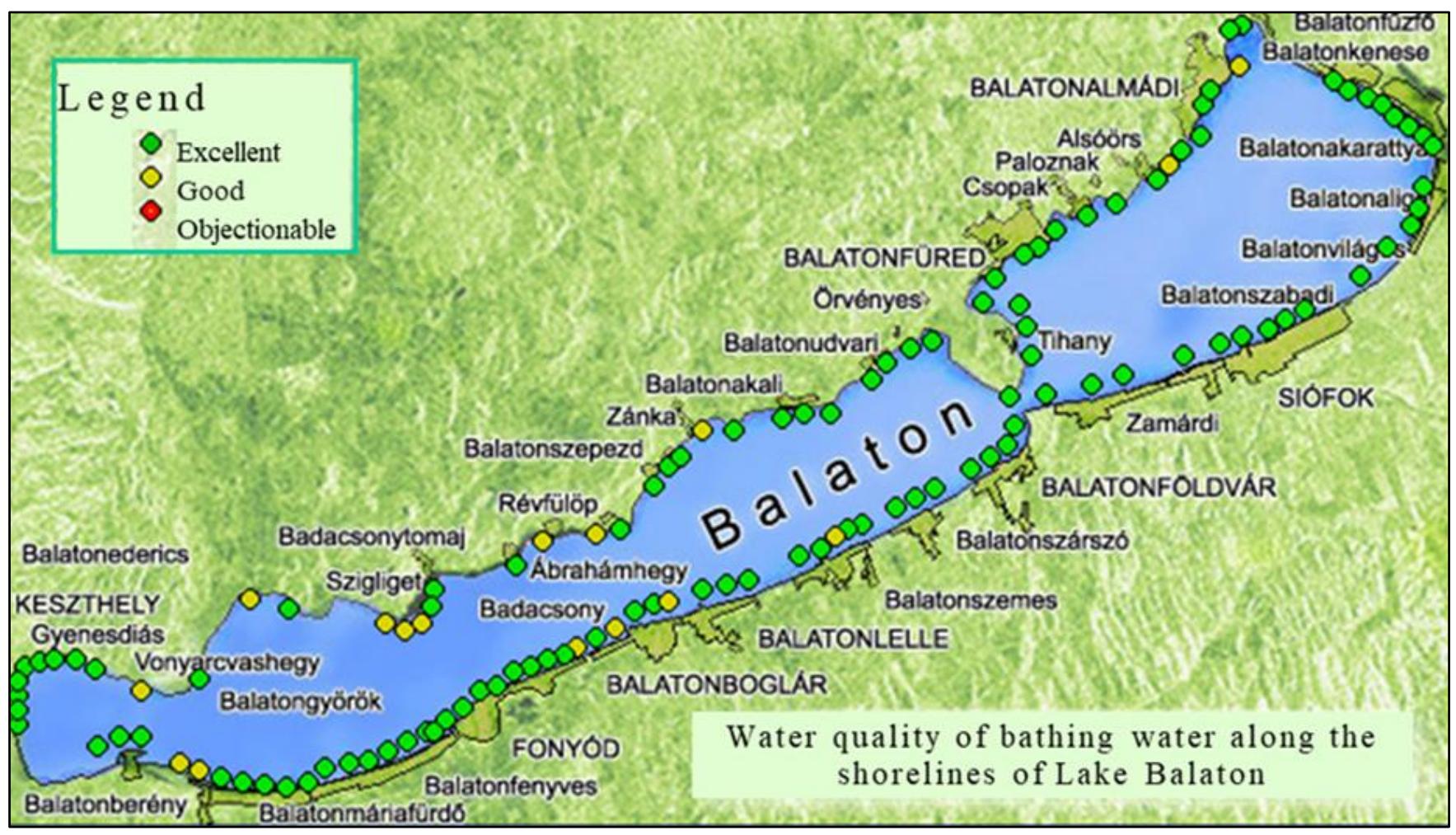

Figure 25. Example of water quality report of bathing sites ("beaches") along the shores of Lake Balaton (source: http://www.kvvm.hu/szakmai/balaton/lang hu/vizmb tk.htm

\begin{tabular}{|c|c|c|c|c|}
\hline System & Balaton & $\begin{array}{c}\text { Tributaries } \\
\text { total }\end{array}$ & $\begin{array}{c}\text { Tributaries } \\
\text { mouth section }\end{array}$ & $\begin{array}{c}\text { Lake Balaton } \\
\text { sediment }\end{array}$ \\
\hline 1. Before 2005 (16/2001 KöM-KöViM-EüM) & 300 & 1208 & 572 & 22 \\
\hline 2. After 2005 (31/2004 KvVM- VKI) & 48 & 268 & 88 & 0 \\
\hline Ratio $1 / 2$ & 0.16 & 0.22 & 0.15 & 0 \\
\hline
\end{tabular}

Table 6. Number of samples per year required by the former national monitoring system and the new one "harmonized" to the EU Water Framework Directive (based on: Hungarian National Legislation Database, njt.hu)

The map version of the present monitoring system of surface waters in the Lake Balaton "direct" catchment (Hungarian subunit 4.2) is shown in Figure 26. Compared to the wellestablished $^{7}$ monitoring system that was in use up to 2005 , the present system does not provide sufficient amount of information for the estimation of nutrient and other pollutant load to such a valuable natural and economic asset. More than 3 decades-long time series data were interrupted in 2005, and it became rather problematic (if not impossible) to make an of the $77 \mathrm{~km}$ long lake, and 3 on important tributaries. The 12 samples/year frequency compares to the 52 samples/year of the former system. There are some 35 tributaries discharging into the lake. Zala river and two other streams are included in the surveillance monitoring, but the 2nd and 3rd largest rivers are not. It is highly improbable that by taking only 12 samples a year from the three tributaries flash flood or other flood events would be sampled. This is rather regrettable since flood events may carry the larger part of pollutants and nutrients into the lake. 
In addition, taking 6 phytoplankton samples provides negligible information on the dynamics of phytoplankton growth and events of mass blooms cannot be predicted or even they would develop and regress without the detection by the monitoring system (the ecosystem or bathing people would "detect" them, however).

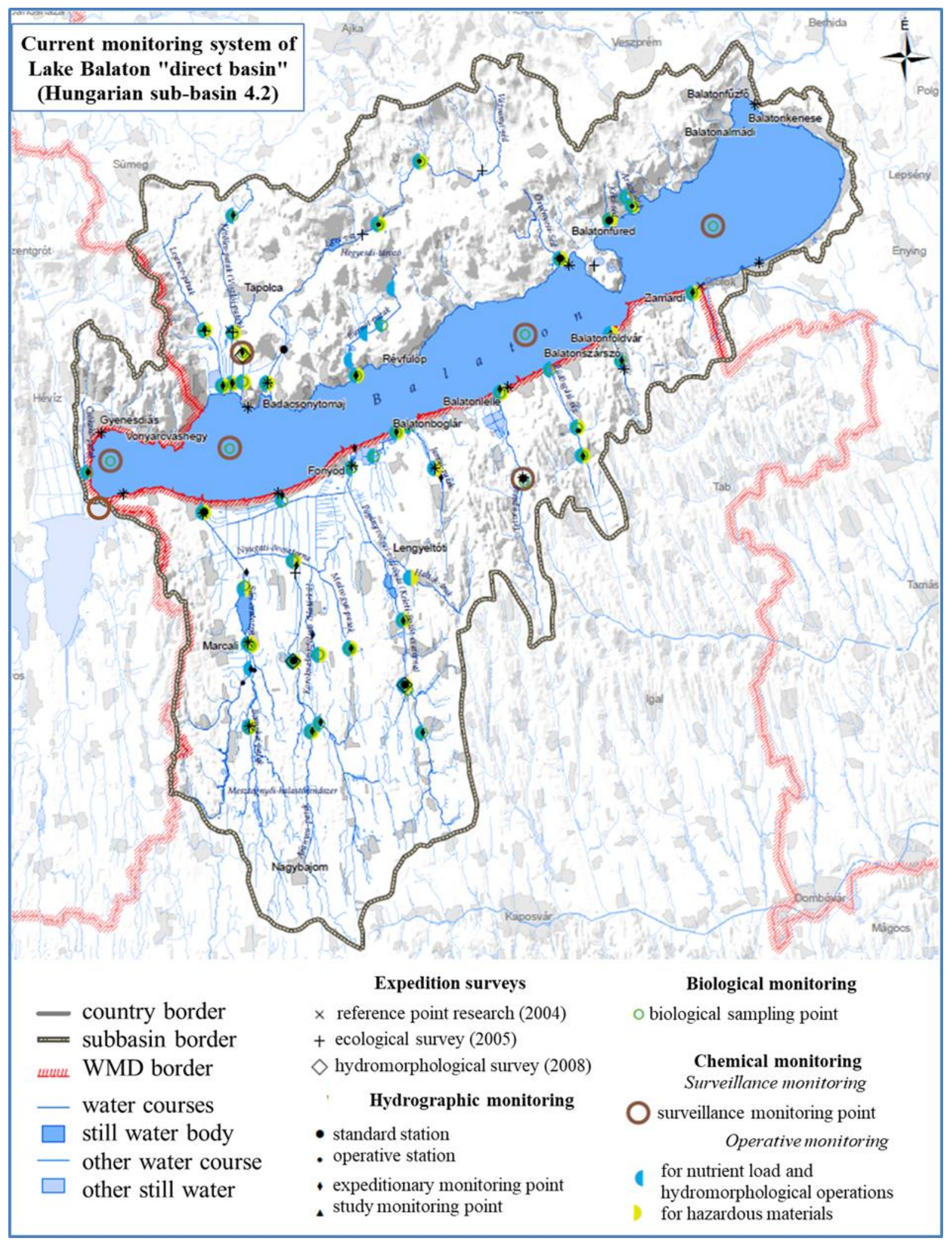

Figure 26. Monitoring system of Lake Balaton watershed "direct" sub-watershed (4-2) (KDT VIZIG, 2016) 


\begin{tabular}{|l|c|c|c|}
\hline \multicolumn{1}{|c|}{ Characteristics } & $\begin{array}{c}\text { Lake Balaton* } \\
\text { (HUSWPS_1LW) }\end{array}$ & $\begin{array}{c}\text { Tributaries** } \\
\text { (HUSWPSW_1RW) }\end{array}$ & Notes \\
\hline Number of monitoring points & 4 & 3 & \\
\hline Sampling frequency samples/year & 12 & 12 & Once in 6 years \\
\hline Basic chemistry*** & 12 & 12 & Once in 6 years \\
\hline Priority pollutants (WFD Annex X.) & 12 & 12 & \\
\hline Other hazardous substances & 6 & 4 & \\
\hline Phytoplankton & 0 & 0 & \\
\hline Lake sediment & & \multicolumn{2}{|l|}{} \\
\hline
\end{tabular}

Table 7. Characteristics of surveillance monitoring points in the Lake Balaton watershed (based on njt.hu)

Lake sediment is not monitored in the present system, even though the internal phosphorus load may become very high under specific hydro-meteorological conditions (e.g. long, hot spells with high water temperature followed by one or more short storm events). In such cases part of the solidsadsorbed phosphorus is mobilized and accumulates in the pore water of the sediment. Then, by sediment resuspension it is transferred into the water column and may cause phytoplankton bloom.

\subsection{Algae that cause new concerns}

Data shown in Figure 23 and 24 indicate that chlorophyll-a concentration, a measure of phytoplankton abundance shows a decreasing trend (with the exception of the period of extreme drought and associated lake level drops from 2000 to 2004). However, during the period of extreme low lake water level - some $80 \mathrm{~cm}$ below normal (meaning some $24 \%$ loss of lake water volume) mass growth of filamentous green algae (Cladophora glomerata) occurred in the shallow water (Figure 27).

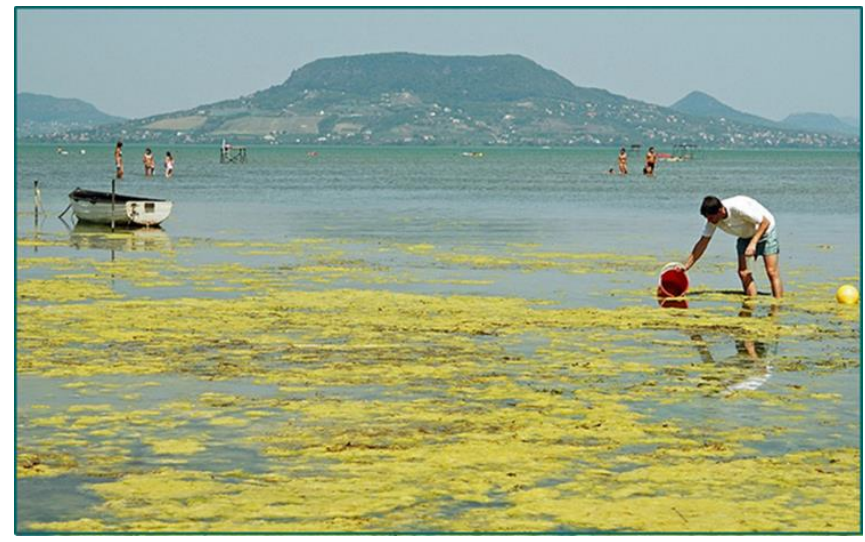

Figure 27. Mass growth of filamentous green algae (Cladophora glomerata) in the extremely shallow parts of Lake Balaton (https://ilovebalaton.blog.hu)

Experience shows that the areas affected are those with $50 \mathrm{~cm}$ water depth or less. During the serious level drop period this area included the whole southern shoreline zone in several hundred metres width. In addition to low water depth, high water temperature $\left(25\right.$ to $\left.30{ }^{\circ} \mathrm{C}\right)$ is also a factor in the mass production of this alga. Unlike planktonic blue-green algae, this species does not produce toxins, but it is an aesthetic challenge to bathe in Cladophora infested water. Another problem is that waves throw the massive algae mats on the riprap along the shores where the thick algal mat may rot and cause odour or other nuisance.
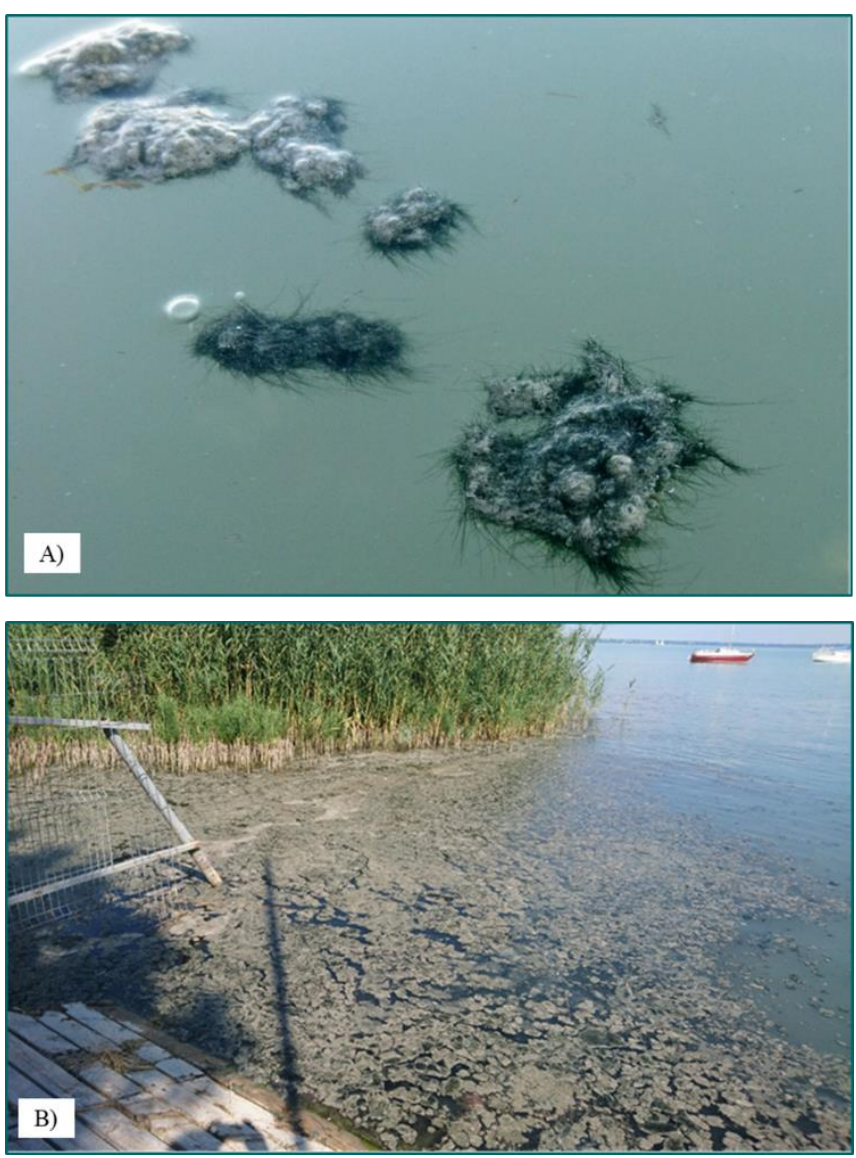

Figure 28. A) Benthic algae with sediment particles floating up to the surface of the water in Lake Balaton. B) Winddriven, floated-up, partially dried benthic algae mat near a beach (Photos of Jakab L. in Vörös L., 2017)

Since phytoplankton concentration decreased in recent years, their shading effect also decreased allowing more light to penetrate to the bottom of the lake. Getting enough light to grow, a recently emerged problem is the growth of filamentous algae (e.g. Oscillatoria sp.) on the phosphorusrich sediment surface, and floating-up of algae patches together with sediment particles to the surface through the buoyancy effect of oxygen bubbles produced by photosynthesis (Fig. 28). This phenomenon is also related to relatively small water depths (less than $2 \mathrm{~m}$ ) therefore, bathing areas are affected most. It is mostly an aesthetic 
problem but may have economic consequences by discouraging bathing tourists in the summer season. The two type of algae mentioned are not monitored at all therefore little quantitative data (only through research by Lake Balaton Research Institute) exist on their biomass (Vörös L, 2013)

\subsection{Climate change and water level/balance problems}

The extreme drought period from year 2000 to 2004 is widely attributed to one of the first manifestations of climate change. Lake level in 2003 dropped to $23 \mathrm{~cm}$ gauge (normal level is about $1 \mathrm{~m}$ ). In addition, the natural water balance, i.e. (direct precipitation + inflow) - evaporation became negative for the first time since 1921, the starting year of systematic and accurate data collection on water balance elements. Figure 29 shows the annual water balance since 1921 . What really gives cause for concern is the fact that the natural water balance was negative 7 times in the last two decades (Kutics K, et al., 2016).

The consecutively occurring negative water balance prompted several research and management projects. One of them is the EU-Lakes project sponsored by the Central European Program of the EU. Impacts of climate change on Central European Lakes were studied and common policies developed. Using some of the output of the project, changes store water for drought periods, the maximum level of Lake Balaton was increased by $10 \mathrm{~cm}$, to $110 \mathrm{~cm}$ gauge. The serious level drop of 2012 (38 cm gauge) prompted studying the feasibility of increasing the maximum allowable level to $120 \mathrm{~cm}$ which was approved in 2018 .

Just as the final draft of this paper was going to be finished (end of August - beginning of September, 2019), a very serious algal bloom developed, after a long and extremely hot period at the beginning of September, in the Keszthely and Szigliget basins with chl-a concentrations as high as 314 $\mathrm{mg} / \mathrm{m}^{3}$ indicating the inherent vulnerability of the water quality of Lake Balaton.

Effect of climate change on water quality was studied by the four-basin eutrophication model BHTWaQeKK described elsewhere. ${ }^{8}$ Basin parameters used are shown in Table 8. Using climate change prediction data from the EU-Lakes project, annual maximum chlorophyll-a concentrations were calculated for the four basins. In addition to the effect of climate change, two phosphorous load scenarios were also studied. Scenario 1 was the baseline (no action, no load reduction) and Scenario 2 assumed an ambitious 50\% phosphorus load reduction. Results of the model simulations are summarized in Figure 31. All results are expressed as percentage changes as compared to the reference conditions.

\begin{tabular}{|c|c|c|c|c|c|c|}
\hline Property & Unit & $\begin{array}{c}\text { Basin } 1 \\
\text { Keszthely }\end{array}$ & $\begin{array}{c}\text { Basin } 2 \\
\text { Szigliget }\end{array}$ & $\begin{array}{c}\text { Basin } 3 \\
\text { Balatonszemes }\end{array}$ & $\begin{array}{l}\text { Basin } 4 \\
\text { Siófok }\end{array}$ & Total \\
\hline Area & $\mathrm{km}$ & 36 & 144 & 186 & 218 & 584 \\
\hline Average depth & $\mathrm{m}$ & 2.28 & 2.87 & 3.23 & 3.68 & 3.25 \\
\hline Volume & million $\mathrm{m}^{3}$ & 82 & 413 & 600 & 802 & 1897 \\
\hline Inflow & million $\mathrm{m}^{3} / \mathrm{y}$ & 307 & 187 & 59 & 27 & 577 \\
\hline Precipitation & million $\mathrm{m}^{3} / \mathrm{y}$ & 24 & 90 & 116 & 143 & 373 \\
\hline Evaporation & million $\mathrm{m}^{3} / \mathrm{y}$ & 34 & 132 & 170 & 209 & 545 \\
\hline Outflow & million $\mathrm{m}^{3} / \mathrm{y}$ & 297 & 439 & 444 & 405 & 405 \\
\hline Mean res. time & year & 0.28 & 0.95 & 1.35 & 1.98 & 4.7 \\
\hline
\end{tabular}

Table 8. Morphological parameters and water balance of the 4 basins of Lake Balaton at $64 \mathrm{~cm}$ water level (based on Herodek et al., 1988)

in the natural water balance of Lake Balaton were predicted for the 21 st century (Figure 30 ). According to the predictions, water balance of the lake deteriorates, water outflow decreases, and the lake turns to an endorheic one in the second half of the century. The consequences might be quite serious with level drop, area contraction, salt concentration growth and general deterioration of water quality.

To prevent unusual lake level drop, a new water level regulation system was introduced right after the crisis years of 2000-2004. Since the terrain of the watershed of the lake does not allow the construction of large capacity reservoirs to
As it can be seen, in case of load Scenario 1, deterioration of water quality starts after 2031 and the maximums are more than 1.8 times larger than the reference value. The water quality deterioration is more obvious in the eastern basins, where the original water quality was better. A $50 \%$ phosphorus load reduction allows less deterioration, but the water quality turns to the worse around the end of the century. The reasons of WQ deterioration are as follows: higher growth rate of algae due to increased temperature, higher degree of immobilization of phosphorus accumulated in the sediment due to higher mass transfer rates, more frequent 
oxygen depletion in the sediment and the shift in the adsorption equilibrium of phosphorus.

Thus, internal phosphorus load increases allowing higher rate phytoplankton growth. In the upper $10 \mathrm{~cm}$ layer of Lake Balaton sediment there is about 16,500 tons of phosphorus accumulated. This corresponds to about 110 years of external phosphorus load, so it is not an overstatement to say that the internal load is going to play an important part in determination of water quality in the coming decades. These results and the new algae problems described in Section 6.2. indicate that ambitious nutrient load reduction programs should be implemented in the coming years. To stabilize and improve the water quality of Lake Balaton, nutrient loads carried by water courses as well as by direct urban and agricultural runoff have to be reduced by a wide margin. A new program containing several measures to this effect has just started.

\section{Implications for the Balaton Ecomuseum project}

The Balaton Ecomuseum, the world's largest ecomuseum with an area of $8,500 \mathrm{~km}^{2}$ is being established now, originally initiated within the framework of the Interreg Central Europe project CULTURECOVERY. ${ }^{9}$ An ecomuseum is a landscape area developed as an open-air museum, linking the natural environment, its ecosystem services and the cultural heritage components of the landscape into one holistic unit, focused on the identity of a place, largely based on local participation and aiming to enhance the welfare and development of local communities. The new, holistic concept of cultural landscapes constitutes the basis of the Balaton Ecomuseum: A cultural landscape is a geographic area, with all its cultural and natural resources, the wildlife and domestic animals, natural and artificial ecosystems, the built and intangible heritage therein, continuously shaped by historic and presentday evolutionary processes including the adverse or beneficial impacts of human activities, social relations and evolving cultures, which mirror the evolutionary trends of human society (Némethy, 2019). Community involvement and active participation is essential for all ecomuseums. By the close cooperation between local and regional authorities, churches, businesses, university departments, private professionals and professional organisations and scientific networks, new study areas for informal public education will emerge that will be able to facilitate sustainable rural development while at the same time establish close ties to the professional field. Ecomuseums have a very important role in the development of sustainable tourism, considering their role in public, non-formal education and in the progressive preservation of all categories of cultural heritage using them as touristic products managed and maintained by the local communities.

Linking economic, social, cultural and environmental considerations, rural tourist attractions are assets which

${ }^{9}$ The CULTURECOVERY project (Programme: 2014 - 2020 INTERREG VB Central Europe) focuses on the protection and RECOVERY of immaterial CULTUural heritage of cannot be reproduced, and they should be treated, protected and allocated as scarce resources to correct the adverse impacts of those market mechanisms, which do not show their normal allocative functions (Némethy et. al. 2017). Many touristic destinations are associated with mass tourism, large scale construction and infrastructure development, which can result in the destruction of these sites, creating hereby the paradox of short-sighted economies: the tourism destroys its own destination. Therefore, the key to planning and managing sustainable rural tourism is the assessment of the carrying capacity of ecosystems and the available ecosystem services of each touristic destination, taking into consideration the possible highest tourist-pressure in each season and constructing regulatory mechanisms to keep the environmental load within acceptable limits.

Good (or rather excellent) water quality of Lake Balaton is a precondition to the good ecological status of Lake Balaton watershed as well as the health and livelihood of the population living in the region. Lake Balaton watershed and its vicinity are full of unique ecological values. Large part of the area is National Park, Natura 2000 area, Ramsar site or ex lege protected wetland. The wildlife and biodiversity as well as the stock of unique domestic animals (Hungarian grey cattle, water buffalo, Mangalica pig, Racka sheep, etc.) are organic part of the landscape. It is also rich in historical monuments, valuable built environment.

The Balaton Ecomuseum can be a successfully implemented project only if Lake Balaton maintains its good and constantly improving water quality and attractiveness for the people of Hungary and Europe. Acronyms

\begin{tabular}{|c|c|}
\hline EU & European Union \\
\hline EU-WFD & $\begin{array}{l}\text { Water Framework Directive of the } \\
\text { European Union }\end{array}$ \\
\hline FTU & Formazin Turbidity Unit \\
\hline KDT-KÖFE & $\begin{array}{l}\text { Central Transdanubian Environmental } \\
\text { Inspectorate }\end{array}$ \\
\hline KDT VIZIG & $\begin{array}{l}\text { Central Transdanubian Water } \\
\text { Management Directorate }\end{array}$ \\
\hline $\mathrm{KSH}$ & Central Office of Statistics, Hungary \\
\hline KvVM & Ministry of Environment and Water \\
\hline LBDC & Lake Balaton Development Council \\
\hline LBDCA & $\begin{array}{l}\text { Lake Balaton Development Coordination } \\
\text { Agency }\end{array}$ \\
\hline LBRA & $\begin{array}{l}\text { Lake Balaton Recreational Area ("Balaton } \\
\text { Region") }\end{array}$ \\
\hline OVF & $\begin{array}{l}\text { National General Directorate of Water } \\
\text { Management }\end{array}$ \\
\hline U.S.-EPA & $\begin{array}{l}\text { United States Environmental Protection } \\
\text { Agency }\end{array}$ \\
\hline WQ & Water quality \\
\hline
\end{tabular}

Central Europe through Ecomuseums, as driver of microregional growth, aiming to turn "traditional/standard" management models into innovative performing ones. 


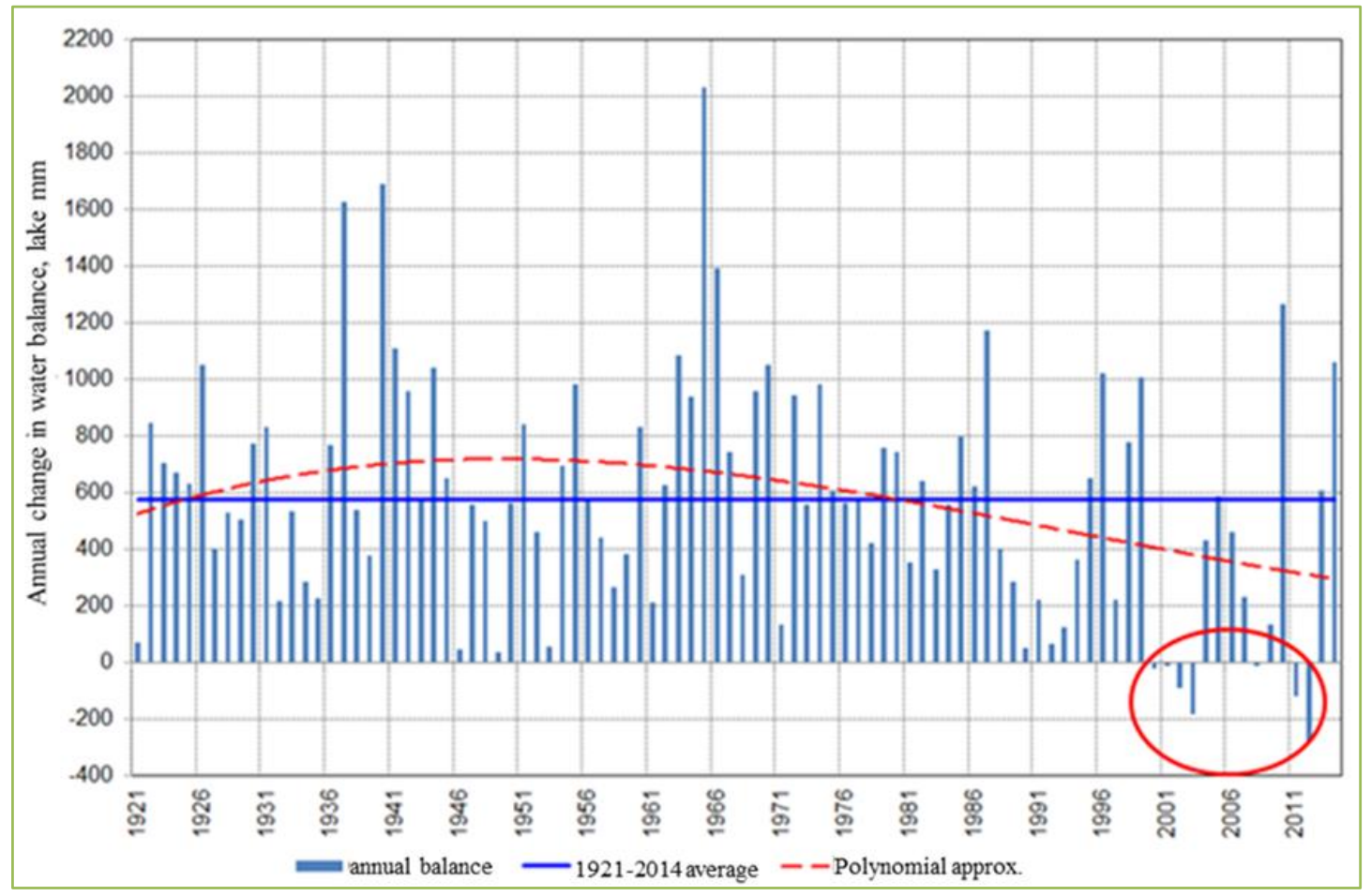

Figure 29. Long-term changes in the annual natural water balance of Lake Balaton (Kutics K. et al, 2016)

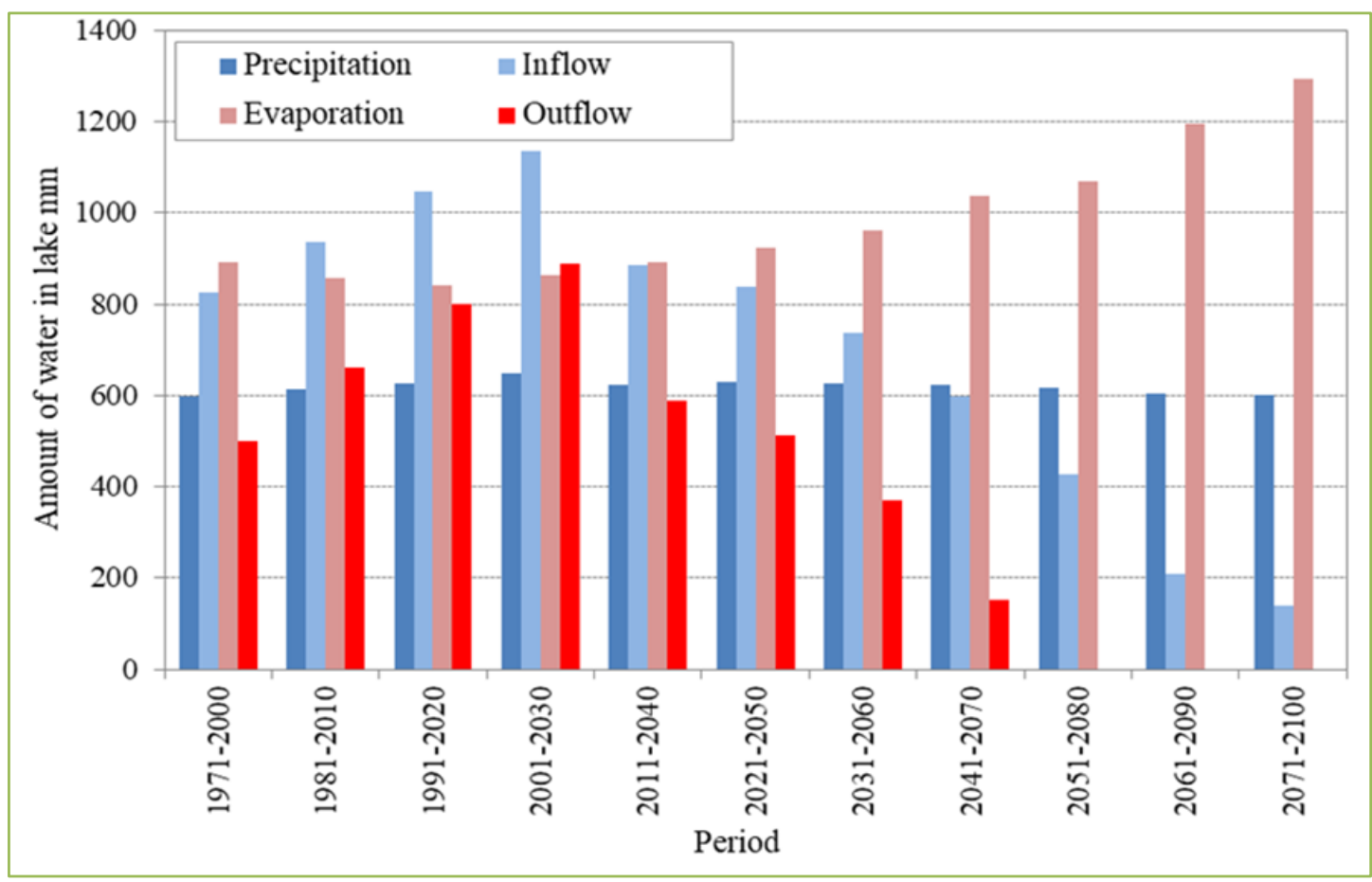

Figure 30. Prediction of the change of water balance elements of Lake Balaton based on regional A1b climate scenario (Kutics K. et al., 2016) 


\section{References}

Ambrose, R.B., et al. (1993): The Water Quality Analysis Simulation Program, WASP5, version 5.10. U.S. EPA, Athens, GA.

Bendefy L. \& V. Nagy I. (1969): Shoreline changes of Lake Balaton during centuries. In Hungarian (A Balaton évszázados partvonalváltozásai) pp. 215, Müszaki Könyvkiadó (Technical Publishing Co.), Budapest

BKÜ Helyzetelemzés (2013): A Balaton Kiemelt Üdülőkörzet Hosszútávú Területfejlesztési Koncepciója 2014-2020 Helyzetelemzés. Készítette a Balatoni Integrációs és Fejlesztési Ügynökség Közhasznú Nonprofit Kft. 2013. http://www.balatonregion.hu/a_balaton_regio_201420_terve zesi_feladatai_dokumentumai

Briand, J.-F. et al. (2004): Cylindrospermopsis raciborskii (Cyanobacteria) invasion at mid-lattitudes: selection, wide physiological tolerance or global warming? Journal of Pycology, 40, pp. 231-238.

DOI: $10.1111 / \mathrm{j} .1529-8817.2004 .03118 . \mathrm{x}$

Brown, L.C. et al. (1987): The Enhanced Stream Quality Models QUAL2E and QUAL2E-UNCAS, EPA/600/3$87 / 007$.

Coastal Engineering Research Center (CERC) (1977): Shore Protection Manual, Vol. 1, U.S. Army Corps of Engineers, Fort Velvoir, VA.

Di Toro, D. M. (1978): “Optics of Turbid Estuarine Waters: Approximations and Applications," Water Research, No. 12, pp. 1059-1068, 1978.

DOI: $10.1016 / 0043-1354(78) 90051-9$

Geider, R.J. et al. (1997): Dynamic model of phytoplankton growth and acclimation: responses of the balanced growth rate and the chlorophyll-a: carbon ratio to light, nutrientlimitation and temperature. Marine ecology Progress Series, 140, pp. 187-200.

Gelencser, P., Szilágyi, F., Somolyódy, L., and Lijklema, L.(1982): "A study on the influence of sediment in the phosphorous cycle in Lake Balaton," Collaborative Paper, CP-82-4, Internat. Inst. Appl. Systems Analysis (IIASA), Laxemburg, Austria, 73 p.

Gockler L. (2014): Changes in domestic livestock between 2000 and 2013. (In Hungarian. A hazai állatállomány változása 2000 és 2013 között). Agricultural Technology, March 2014. (Mezőgazdasági Technika 2014. március), HU ISSN 0026 1890, NAIK Institute of Agricultural Mechanization (Mezőgazdasági Gépesítési Intézet), Gödöllő

Hakanson, L. (1982): Lake bottom dynamics and morphometry: the dynamic ratio. Water Resources Research, vol. 18, no. 5 , p. $1444-1450$.

DOI: $10.1029 / \mathrm{WR} 018 \mathrm{i} 005 \mathrm{p} 01444$

Herodek, S., Laczkó, L., Virág, Á. (1988): Lake Balaton Research and Management, ILEC, Kusatsu, Nexus Nyomda pp. 110.
Hirayama, A., and Wake, A. (1998): "Eutrophic water-quality modeling incorporating P-release from $\mathrm{SS}$ and algal $\mathrm{P}$-storage (in Japanese)," JSCE, J. Coastal Eng., Vol. 45, pp. 1041-1045.

Horváthné Szigedi K. et al. (2013): Scientific research in the Balaton Region. In Hungarian (Tudományos kutatások a Balaton régióban). Act. Sci. Soc. 39 (2013): 219-238.

Istvánovics, V., Herodek, S., and Szilágyi, F. (1989): "Phosphate Adsorption by Different Sediment Fraction on Lake Balaton and Its Protecting Reservoirs," Water Res., Vol. 23, No. 11, pp. 1357-1366.

DOI: $10.1016 / 0043-1354(89) 90074-2$

James, R. T. et al. (1997): A sediment resuspension and water quality model of Lake Okeechobee. Journal of American Water Resources Association, 33 (3), pp.661-680.

Japan International Cooperation Agency (JICA) (1999): "Environmental Improvement of Lake Balaton, The Republic of Hungary," Final Report, Data Book, No. SSS-JR-99032.

Japan International Cooperation Agency (JICA) (1999): "Environmental Improvement of Lake Balaton, The Republic of Hungary," Final Report, Supporting Report, No. SSS-JR99032.

KDT-KOFE (1994): “Assessment of the Extraordinary Water Quality of Lake Balaton in 1994," (in Hungarian), Internal Report, Székesfehérvár, 93 P.

KDT-VIZIG (1988): "Report on the research activity in 1988: Revealing blue-green algae processes in Lake Balaton and some other topics," (in Hungarian), 33 p.

KDT VIZIG (2016): Lake Balaton River Basin Management Plan (in Hungarian). www.vizeink.hu

Kertész Á. (2011): Changes of land use in the catchment area of Lake Balaton during one century with particular attention to forests. In Hungarian. Publications of the University of Miskolc, A series, Mining, volume 82. (A földhasználat változása a Balaton vízgyüjtőn egy évszázadsorán, különös tekintettel az erdőkre. A Miskolci Egyetem Közleményei, A sorozat, Bányászat, 82. kötet)

Gyarmati, Gy., Püski, L., Barta, R. (1997): Hungary in the $20^{\text {th }}$ century, volume II. Natural environment, population and society, churches and religious organizations, economy. In Hungarian. (Magyarország a XX. Században, II. Kötet. Természeti környezet, népesség és társadalom, egyházak és felekezetek, gazdaság). Editors: Kollega Tarsoly, I., Berkény, I., Dányi, D. Babits Publishing Ltd. Szekszárd, 704 pp. ISBN 963-901-509-1

Jolánkai G. (2007): Tápanyagterhelési mérlegek elkészítése nagy tavainkra, I. a Balaton tápanyagterhelésének mérlege, mérése és modellezése, VITUKI Kht., Témaszám: 7612/31/708501, Budapest, p.27.

Koltay J. (szerk.) (2001): Lake Balaton - our national treasure. In Hungarian. (Nemzeti kincsünk a Balaton), ISBN 963-00-9233-6, pp.413, K\&K-Pro Bt., Budapest

Központi Statisztikai Hivatal (Central Office of Statistics, 2013): The census for the year 2011. Regional data, 3.15. 
Somogy County; in Hungarian. (2011. Évi népszámlálás, 3. Területi adatok, 3.15. Somogy megye) ISBN 978-963-235411-8, pp.258, KSH, Pécs

Központi Statisztikai Hivatal (Central Office of Statistics, 2013): The census for the year 2011. Regional data, 3.19. Veszprém County; in Hungarian. (2011. Évi népszámlálás, 3. Területi adatok, 3.19. Veszprém megye), ISBN 978-963-235415-6, pp.260, KSH, Veszprém

Központi Statisztikai Hivatal (Central Office of Statistics, 2013): The census for the year 2011. Regional data, 3.20. Zala County; in Hungarian. (2011. Évi népszámlálás, 3. Területi adatok, 3.20. Zala megye), ISBN 978-963-235-416-3, pp.296, KSH, Győr

Kutas, T., Herodek, S. (1986): A complex model for simulating the Lake Balaton Ecosystem. In: Somlyódy, L., and van Straten, G. (Eds.): Modeling and Managing Shallow Lake Eutrophication, Springer Verlag, pp. 323-340.

ISBN 978-3-642-82707-5

Kutics K. (2008): A Balaton Régióra vonatkozó indikátor rendszer kialakítása és egyes indikátorok összefüggéseinek elemzése. Comitatus, XVIII/8, 174. szám. Megyei Önkormányzatok Országos Szövetsége, Veszprém.

Kutics K. and Molnár G. (2013): Could climate change cancel out the results of water quality control measures at Lake Balaton? Geophysical Research Abstracts. 2013.15. EGU2013-12333.

Kutics, K. (2011): Reducing the nutrient load of Lake Balaton, protection of water quality. In Hungarian. Research report, LBCDA, Siófok. (A Balaton tápanyagterhelésének csökkentése, vízminőség védelme. Kutatási jelentés. Balatoni Integrációs Nonprofit Kft., Siófok.

Kutics, K. (2013): Sekély tavak jellegzetességei és problémái Acta Scientiarum Socialium 39 (2013): 11-34., Kaposvári Egyetem, ISSN: 1418-7191.

Kutics, K. (2015): The History ff Human Interventions in the Environment of Lake Balaton, in Molnár G. et al. (ed.): Interaction of Natural and Social Processes in Shallow Lake Areas, Kaposvár Univesity, ISBN 978-963-9821-96-5.

Kutics K., Kravinszkaja, G., Varga Gy. (2016): A Balaton és teljes vízgyüjtő-területének átfogó hidrológiai vizsgálata, különös tekintettel a lefolyási viszonyok drasztikus változására és a hozzáfolyás csökkenésére, MHT XXXIV. Országos Vándorgyülés dolgozatai, No.19.., Debrecenben, 2016. július 6-8. ISBN 978-963-8172-35-8

Lahlou, M., L. Et Al. (1998): Better Assessment Science Integrating Point and Nonpoint Sources, BASINS Version 2.0 User's Manual. EPA EPA-823-B-98-006. U.S. EPA, Washington, DC.

Lencsés, E. (2013): Economic evaluation of precision (place specific) horticulture. $\mathrm{PhD}$ thesis, in Hungarian. (A precíziós (hely-specifikus) növénytermelés gazdasági értékelése). Szent István University, Gödöllö.
Leuttich, R. A., and Harleman, D. R. F. (1986): “A Comparison of Water Quality Models and Load Reduction Predictions," In Somlyódy, L., and van Straten, G. (Eds.); Modeling and Managing Shallow Lake Eutrophication, Springer Verlag, pp. 323-340. ISBN 978-3-642-82707-5

NÉBIH (National Food Safety Office) (2019): Ragweed maps 2011-2019.

http://airterkep.nebih.gov.hu/gis_portal/pir/pir.htm

Némethy, Sandor; Walas, Bartlomiej; Lagerqvist, Bosse (2017): The role of ecosystem services in rural tourism: Evaluation of carrying capacity of touiristic destinations in ecologically sensitive rural areas to prevent over-exploitation. JOURNAL OF CENTRAL EUROPEAN GREEN INNOVATION 5:1 pp. 29-40, 12 p. (2017)

Némethy, S. and Molnár, G. (2014): Sustainable management of lakes in connection with mitigation of adverse effects of climate change, agriculture and development of green micro regions based on renewable energy production. EQA Environmental quality / Qualité de l'Environnement / Qualità ambientale, 13 (2014) 21-35.

https://doi.org/10.6092/issn.2281-4485/4527

Némethy, Sándor (2019): The Balaton Ecomuseum Touristic Product and Landscape Management in One System. In English with English and Polish abstract; chapter in monography: Parki Narodowe i Otoczenie Społeczno Gospodarcze. Skazani na Dialog (National Parks and the Socio - economic Environment. Condemned to Dialogue) pp. 175 - 203. Wyższa Szkoła Turystyki i Ekologii w Suchej Beskidzkiej, ISBN 978-83-947044-1-4

Pallas Kiadó.(1893-1897): Pallas Nagy Lexikona, Budapest, (The Great Lexikon of Pallas)

Pálmai, O. (2010): Sustainable use of agricultural land and use of agrochemicals. In Hungarian. (A fenntartható termőföldhasználat és az agrárkemizálás) Székesfehérvár, on the $11^{\text {th }}$ of May, 2010.

Papp F. (2005): Zsuzsanna és az algák avagy a Keszthelyi medence vízminőségvédelmi kotrása.

http://www.aquadocinter.hu/themes/Vandorgyules/pages/3sz ekcio/papp.htm

Présing, M., Herodek, S., Vörös, L., and Kóbor, I. (1996): "Nitrogen fixation, ammonia and nitrate uptake during a bloom of Cylindrospermopis raciborskii in Lake Balaton," Arch. Hydrobiol., Vol. 136, No. 4, pp. 553-562.

https://hungary.pure.elsevier.com/en/publications/nitrogenfixation-ammonium-and-nitrate-uptake-during-a-bloom-of-c

Rátz T. (1999): The socio-cultural impacts of tourism. PhD thesis; in Hungarian. (A turizmus társadalmi-kulturális hatásai), Budapesti Közgazdaságtudományi Egyetem, Budapest.

Sebestyén O. (1958): Quantitative Plankton Studies on Lake Balaton; IX. A summary of the biomass studies. In Annal. Biol. Tihany (ed.: Entz B.), pp. 281-292. 
Shafik, H. M., Vörös, L., Présing, M., and Kovács, A. (1987): "Growth of Cylindrospermopis raciborskii in batch and continuous cultures," (a report in Hungarian), pp. 17-18.

Somlyódy, L., van Stranen, G. (eds, 1986): Modeling and Managing Shallow Lake Eutrophication, With Application to Lake Balaton, Springer Verlag, Berlin, pp. 386, ISBN 9783642827099

Sommer, U. (1984): "Sedimentation of principal phytoplankton species in Lake Constance," Journal of Plankton Research, Volume 6, Issue 1, 1984, Pages 1-14.

DOI: $10.1093 /$ plankt/6.1.1

Szilassi P. (2006): A területhasználat változásának tendenciái Balaton vízgyüjtőjén a településsoros statisztikai adatok tükrében (K 60203 számú OTKA pályázat)

http://www2.sci.u-szeged.hu/eghajlattan/baba/Szilassi.pdf

Szlávik, L. (szerk.) (2005): Lake Balaton. In Hungarian. Hydrological communications (Vízügyi Közlemények; különszám), Special issue. pp. 477, HU-ISSN 0042-7616, Környezetvédelmi és Vízügyi Minisztérium, Budapest. www.vizugyikozlemenyek.hu

Szári Zs. (2013): Fish stocking and catch data of the Lake Balaton Fisheries Co. Ltd. Personal communication and data provision.

Virág Á. (1998): Past and Present of Lake Balaton, Egri Nyomda, Eger, pp.904. ISBN 9639060216.
Vörös L., In Herodek et al. (1988): Lake Balaton Research and Management, ILEC, Kusatsu, Nexus Nyomda, p. 38-39.

Vörös L., Kravinszkaya G., Présing M., V-Balogh K., Tóth V.: et al (2013): Social Conflict Generating Ecological Developments in the Life of Lake Balaton in Recent Decades - Effect of water level fluctuation on the plants of the littoral zone, Act Sci Soc 39 (2013): 83-94.

Zasadni, J. and Kłapyta, P. (2014): The Tatra Mountains during the Last Glacial Maximum Journal of Maps, 2014 Vol. 10, No. 3, 440-456,

DOI: $\underline{10.1080 / 17445647.2014 .885854}$

\section{Web references:}

http://www.hydroinfo.hu

http://www.ksh.hu/docs/hun/xstadat/xstadat_eves/i_omn010. $\underline{\mathrm{html}}$

http://www.nyuduvizig.hu/index.php/vizrendezes/kisbalaton/kis-balaton-eredmenyek

http://www.geo.info.hu/portal2007/images/stories/hirek/201 0/20100511/palmaio termofold.pdf

Szilágyi F. (2010): http://www.vkkt.bme.hu/feltoltesek/2010/10/kisbalaton_szf. $\mathrm{ppt}$

(C) 2019 by the author(s). This article is an open access article distributed under the terms and conditions of the Creative Commons Attribution (CC BY) license (http://creativecommons.org/licenses/by/4.0/). 